\title{
Amendment Properties Affect Crop Performance, Leaf Tissue Nitrogen, and Soil Nitrogen Availability Following Soil Treatment by Anaerobic Soil Disinfestation
}

\author{
Utsala Shrestha*, Keagan J. Swilling and David M. Butler* \\ Department of Plant Sciences, University of Tennessee, Knoxville, TN, United States
}

Efficacy of anaerobic soil disinfestation (ASD) for soilborne plant pathogen suppression

OPEN ACCESS

Edited by:

María Del Mar Guerrero,

Instituto Murciano de Investigación y

Desarrollo Agrario y Alimentario

(IMIDA), Spain

Reviewed by:

Senorpe Hiablie,

The Pennsylvania State University

(PSU), United States

Claudia Marques-dos-Santos

Cordovil,

University of Lisbon, Portugal

${ }^{*}$ Correspondence: David M. Butler

dbutler@utk.edu

Utsala Shrestha

utsala@utk.edu

Specialty section:

This article was submitted to

Waste Management in

Agroecosystems,

a section of the journal

Frontiers in Sustainable Food Systems

Received: 13 April 2021

Accepted: 30 July 2021

Published: 24 August 2021

Citation:

Shrestha U, Swilling KJ and Butler DM (2021) Amendment Properties Affect

Crop Performance, Leaf Tissue Nitrogen, and Soil Nitrogen Availability Following Soil Treatment by Anaerobic Soil Disinfestation.

Front. Sustain. Food Syst. 5:694820.

doi: 10.3389/fsufs. 2021.694820 is strongly influenced by soil environment and organic amendment attributes. At the same time, these factors influence soil nutrient availability, crop nutrition, and crop performance, but published information on ASD amendment property effects, including carbon to nitrogen (C:N) ratio and $\mathrm{C}$ substrate bioavailability, on crop performance and soil nutrient availability is limited. We evaluated ASD amendment effects on soil $\mathrm{N}$ availability, crop $N$ status, and solanaceous crop performance in a series of trials: (1) greenhouse/growth chamber study of amendments (primarily molasses/soybean hulls and wheat bran) formulated at 10:1, 20:1, 30:1 and 40:1 C:N ratios (4 $\mathrm{mg} \mathrm{C} \mathrm{g}^{-1}$ soil), (2) field study with molasses/soybean hull-based amendments at equivalent $\mathrm{C}: \mathrm{N}$ ratios/C rates (3) on-farm study with molasses/soybean hull-based amendments (4 mg C g ${ }^{-1}$ soil) compared to grower-standard control, and (4) field study of labile to recalcitrant amendment substrates at 30:1 C:N ratio ( $\sim 3.4 \mathrm{mg} \mathrm{C} \mathrm{g}^{-1}$ soil). ASD amendment C:N ratio strongly influenced soil inorganic $N$ and the lowest (10:1) ratio was associated with highest soil inorganic $\mathrm{N}$ at ASD treatment termination in both trials 1 and 2 , which often persisted into the cropping phase. Accordingly, the lowest amendment $\mathrm{C}: \mathrm{N}$ ratio was also associated with the highest biomass (trail 1), leaf tissue $N$ (trial 2), and crop yield (trials 1,2 ) among treatments, even with application of recommended fertigation rates to all treatments in the field study. In trial 3, ASD treatment induced higher soil inorganic $\mathrm{N}$ and crop yield than the control, but no differences were observed in plant tissue N. In trial 4, more decomposable ASD substrates reduced soil inorganic $N$ at ASD treatment termination, with the highest soil inorganic $\mathrm{N}$ associated with the most recalcitrant amendment, but there was no effect on crop yield. ASD amendment C:N ratio, and to a lesser extent, amendment decomposability, exert a strong influence soil inorganic $\mathrm{N}$ and crop performance. Optimization of ASD treatments for disease management will require simultaneous optimization of crop nutrition practices to facilitate more holistic, less confounded assessment of crop performance and to facilitate recommendations for grower adoption.

Keywords: biological soil disinfestation, organic soil amendments, agricultural by-products, solanaceous crops, soil fertility 


\section{INTRODUCTION}

Anaerobic, or biological, or reductive soil disinfestation has emerged as a biologically-based alternative to soil fumigation for suppression of soil borne pests (Shrestha et al., 2016). Twenty years ago, the technique of using anaerobic decomposition of organic soil amendments to control soil borne pathogens was developed separately in Japan and the Netherlands (Shennan et al., 2014). More recently, research studies on ASD have been conducted in multiple regions and cropping systems of USA. Comprehensive studies and reviews of ASD (Rosskopf et al., 2005; Shennan et al., 2014; Strauss and Kluepfel, 2015) have shown that ASD is a versatile technique that can be adapted regionally by using varying types of locallyavailable organic amendments to control various soil borne pathogens and plant-parasitic nematodes, and with effects on weed pests. ASD has also shown promising effects on yields of horticultural fruit and vegetable crops when compared to non-treated systems and fumigated systems (McCarty et al., 2014; Shrestha et al., 2016; Guo et al., 2017; Paudel et al., 2018; Gilardi et al., 2020). Varying organic amendments can be used as carbon sources for ASD treatment depending on cost effectiveness, availability, and ease of application. Further, application of organic amendments can improve soil physical and chemical properties of soil leading to ASD treatment impacts on vegetable and fruit yield (Butler et al., 2014a). However, limited studies have evaluated ASD impacts on soil nutrients, crop nutrition, or crop performance. Further, existing published work tends to be limited in scope because it was generally not designed to specifically evaluate mechanistic impacts of varying ASD amendment properties on soil/crop nutrients and crop performance.

In this study we evaluate the importance of ASD amendment properties, including C:N ratio, $\mathrm{C}$ rate and substrate decomposability on soil/crop nitrogen and crop performance under environmental conditions typical to the southeastern USA. While ASD implementation relies on relatively simple techniques of amendment incorporation, irrigation to saturate topsoil and covering the treated plot to create anaerobic conditions for a few weeks, optimization of ASD techniques, including amendment characteristics, is essential to optimize effectiveness against pests and simultaneously maintain or improve crop performance (Shrestha et al., 2016). The ASD process relies on the bioavailability of organic matter in ASD amendments, which increases soil microbial respiration leading to strongly anaerobic soil conditions that facilitate shifts to anaerobic microbial decomposition and the formation of anaerobic decomposition metabolites (Shennan et al., 2014). Amendment C:N ratio, rate, and decomposability all potentially affect these microbial decomposition dynamics (Sinsabaugh et al., 2013; Spohn, 2015; Truong and Marschner, 2018), potentially affecting ASD treatment effectiveness for pathogen control (Shrestha et al., 2018a, 2020a). At the same time, soil amendments and their biochemical composition potentially impact a range of soil chemical, physical, and biological properties (Inglett et al., 2005; Butler et al., 2014a) and of these, changes affecting soil nutrient availability are especially important in affecting crop performance post-ASD treatment (Butler et al., 2014a; Di Gioia et al., 2017).

The overall goal of our study was to evaluate ASD amendment composition effects on soil $\mathrm{N}$ availability, crop $\mathrm{N}$ status, and solanaceous crop performance across a series of four greenhouse and field trials. Our hypotheses were that (1) ASD treatments will increase plant biomass and crop yield compared to anaerobic (unamended, saturated and plastic covered; Trials 1,2) or grower standard (compost only; Trial 3) controls and have similar yield to fumigated controls (Trial 2), (2) soil inorganic $\mathrm{N}$, plant tissue $\mathrm{N}$ and plant biomass will increase at lower $(<$ 20:1) ASD amendment C:N ratios compared to higher ASD amendment C:N ratios and controls (Trials 1, 2), and (3) ASD treatments with labile amendments will increase yield compared to recalcitrant ASD amendments at a similar C:N ratio and a control, with similar soil $\mathrm{N}$ and leaf tissue $\mathrm{N}$ among treatments (Trial 4).

\section{MATERIALS AND METHODS}

\section{Trial 1. Growth Chamber/Greenhouse Trial of Amendment Type and C:N Ratio}

A pot trial with two amendment mixtures (dry molasses/soy hull-based, or wheat bran-based) at four C:N ratios was conducted to evaluate C:N ratio effects on soil inorganic N, plant tissue $\mathrm{N}$ and tomato (Solanum lycopersicum L.) fruit and plant biomass following ASD treatment. The experimental design was a factorial completely randomized design with four replicates, which was repeated. The ASD treatment was conducted in an environmental growth chamber (ECG, Chagrin Falls, OH, USA) at $25^{\circ} \mathrm{C}$ for $14 \mathrm{~h}$ and $15^{\circ} \mathrm{C}$ for $10 \mathrm{~h}$ to simulate soil temperature regimes in relevant production regions during spring in Tennessee and similar warm-temperate to subtropical production regions. Top soil [Dewey silt loam (fine, kaolinitic, thermic, typic Paleudult)] from the Organic Crops Unit at the University of Tennessee, Knoxville, TN, USA was collected, sieved $(<10 \mathrm{~mm})$ and mixed in equal proportion with sand $(\mathrm{w} / \mathrm{w})$. Treatment factors included dry molasses/soy hull-based and wheat bran-based amendments (low-cost livestock feed supplements) mixed with either soybean meal (high nitrogen) or corn starch (low nitrogen) amendments to formulate four amendment C:N ratios (10:1, 20:1, 30:1, and 40:1; Table 1) at $4 \mathrm{mg} \mathrm{C} \mathrm{g}^{-1}$ soil (Table 1; also described in Shrestha et al., 2021). Total C and N content of amendments was determined by combustion (Flash EA 1112 NC Soil Analyzer, CE Elantech, Lakewood, NJ, USA) and other nutrient analysis of amendments determined following digestion (Table 1). Amendments were mixed with soil and placed in polyethylene pots $(2.6-\mathrm{L}$ volume, $12-\mathrm{cm}$ diameter by $23-$ $\mathrm{cm}$ height). Pots were saturated with tap water $(\sim 375 \mathrm{~mL}$ $\mathrm{kg}^{-1}$ soil), covered with black polyethylene mulch $(0.032 \mathrm{~mm})$ and secured with heavy-duty rubberbands. Oxidation-reduction electrodes (ORE, Sensorex Corp., Garden Grove, CA, USA) were inserted in each pot to measure redox potential and assess accumulated anaerobic conditions as described in Shrestha 
et al. (2020b). For a control treatment, pots were nonamended, irrigated and covered (i.e., anaerobic control). All treatment pots were incubated for 3 weeks during the ASD treatment period.

After 3-week incubation, soil samples were collected and pots were transferred to a greenhouse (average temperature $25-30^{\circ} \mathrm{C}$ ), and 3-week-old seedlings of dwarf tomato (cv. Florida Lanai) were planted in each pot to evaluate plant growth characteristics. Dried blood meal ( $5 \mathrm{~g} /$ plant) was applied to each pot at 2 weeks after transplanting. Cropping phase soil samples were collected after 3 weeks and fruit weight and number of fruits per plant were recorded at 8 weeks after transplanting. Plants were removed, cleaned and oven dried at $65^{\circ} \mathrm{C}$ for $48 \mathrm{~h}$ and dry biomass of shoots and roots recorded.

\section{Soil pH, Soil Inorganic N}

Subsamples of soil collected were air-dried and sieved $(<2 \mathrm{~mm})$ prior to determining soil $\mathrm{pH}$ and inorganic $\mathrm{N}$. Soil $\mathrm{pH}$ was recorded by inserting a $\mathrm{pH}$ electrode (Orion 3-Star Plus pH Benchtop Meter, Thermo Scientific, Waltham, MA, USA) in suspension of 5 -g soil and $0.01 \mathrm{M}$ $\mathrm{CaCl}_{2}$ (1:2). The value was reported as equivalent soil $\mathrm{pH}$ determined in deionized water by adding 0.6 (Kissel et al., 2009). For inorganic soil $\mathrm{N}$ and total soil $\mathrm{N}$ and C, 5-g of sieved $(<2 \mathrm{~mm})$ soil was extracted with 1$\mathrm{M} \mathrm{KCl}$ for $30 \mathrm{~min}$, centrifuged, and filtered (Whatman 42) prior to colorimetric analyses for $\mathrm{NH}_{4}-\mathrm{N}$ and $\mathrm{NO}_{2}$ $\mathrm{N}+\mathrm{NO}_{3}-\mathrm{N}$ using a microplate spectrophotometer (Powerwave XS, Biotek, Winooski, VT, USA) as described by (Sims et al., 1995).

\section{Leaf/Shoot Tissue N Analysis}

Whole shoot biomass of tomato plants was collected for tissue $\mathrm{N}$ analysis 8 weeks after transplanting. Samples were dried at $65^{\circ} \mathrm{C}$ for $48 \mathrm{~h}$, then ground and analyzed for total $\mathrm{N}$ content by combustion (Flash EA 1112 NC Soil Analyzer, CE Elantech, Lakewood, NJ, USA).

\section{Trial 2. Field Trial of ASD Amendment C:N Ratio Effects on Soil N and Bell Pepper Performance}

A 2-year field study was conducted at the experimental farm located in Plateau Research and Education Center, University of Tennessee, Crossville, TN, USA to evaluate the effect of C:N ratio of ASD amendment on soil inorganic $\mathrm{N}$, plant tissue $\mathrm{N}$, and bell pepper (Capsicum annum L.) crop yield compared to anaerobic and fumigated controls. The soil type according USDA classification system is in the Lily series (fine-loamy, siliceous, semiactive, mesic Typic Hapludult). Treatments included an ASD amendment mixture (molasses/soy hulls) mixed with soybean meal or corn starch to maintain four C:N ratios of 10:1,

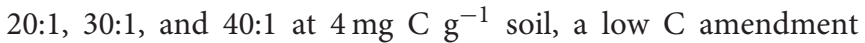
treatment ( $2 \mathrm{mg} \mathrm{C} \mathrm{g}^{-1}$ soil at $\mathrm{C}: \mathrm{N}$ ratio of $30: 1$ ), a nonamended anaerobic control, and a methyl bromide $(\mathrm{MeBr})$ fumigated control (67:33 mixture with chloropicrin, $224 \mathrm{~kg} / \mathrm{ha}$ ) control (Table 1; also described in Shrestha et al., 2021). The experimental design was a randomized complete block with four replications and the experiment was repeated in different sites in 2 years. Soil amendments for ASD treatment were applied in each plot $(7.6 \times 1.8 \mathrm{~m})$ using a drop fertilizer spreader and were thoroughly incorporated with a rotovator. Raised beds $(\sim 5-\mathrm{cm})$ were formed, mulched with standard black polyethylene $(0.025-$ $\mathrm{mm}$, Berry Global, IN, USA) and then drip irrigated $(5 \mathrm{~cm}$ total irrigation applied over $9 \mathrm{~h}$ ) to fill soil pore space to a $\sim 20-\mathrm{cm}$ depth. To assess anaerobic conditions, IRIS (IRIS $=$ indicator of reduction in soils), iron oxihydroxide coated PVC (Castenson and Rabenhorst, 2006) tubes were inserted in each plot at 0 to15$\mathrm{cm}$ depth and were retrieved after the ASD termination. The removal of iron coating was assessed as described by Rabenhorst (2012). Oxidation-reduction electrodes were limited to only one trial within two blocks.

At ASD treatment termination, and 3 weeks after ASD termination, soil samples were collected to determine soil $\mathrm{pH}$ and soil inorganic $\mathrm{N}$ as described in trial 1. Bell pepper transplants (cv. Aristotle F1) were planted at $30-\mathrm{cm}$ between and within a double row per bed (28 to 30 plants per bed) to assess crop performance and plant nutrition. The pepper crop was drip fertigated according to standard grower practice for the southeastern USA (Kemble et al., 2013) beginning the week of transplanting. In total, $148 \mathrm{~kg} \mathrm{~N} / \mathrm{ha}, 36 \mathrm{~kg} \mathrm{P} / \mathrm{ha}$ and $138 \mathrm{~kg} \mathrm{~K} / \mathrm{ha}$ were applied to the crop throughout the growing season, with the final fertigation 2 weeks prior to the last harvest. Pepper fruits were harvested based on size, dark green color, and firmness, and graded according to the standard USDA fruit grading system in fancy, number 1 , number 2 or cull categories (USDA-AMS, 2005). Culled fruits included small, diseased, deformed and sunscalded fruits. Fruits were harvested from each plot (24 to 26 plants), except plants at the end of each row. Plants were harvested once per week from early August to late September in both years. Fruits were counted and weighed in each grade class and summed for each harvest time, then data extrapolated to a per ha basis based on bed length harvested. For leaf tissue N, recently matured, clean pepper leaf tissue $(\sim 20$ leaves per plot) was sampled from 5 randomly selected plants in each plot at 7 weeks after transplanting and leaf $\mathrm{N}$ analyzed as described in trial 1.

\section{Trial 3. On-Farm, High Tunnel Trial of Tomato Crop Performance}

In spring 2016 and 2017 an on-farm evaluation of ASD with molasses and soybean hull-based amendments plus compost amendment compared to a grower-standard control (compost only) was conducted on a privately-owned certified organic vegetable farm, Loudon County, TN, USA to evaluate impacts on soil $\mathrm{pH}$ and soil $\mathrm{N}$ changes over time, tomato leaf tissue $\mathrm{N}$, and tomato yield. The soil type was Litz silt loam (mixed, active, mesic Ruptic-Ultic Dystrudept). The trial began in midFebruary and concluded at the end of the tomato growing season in mid-July. The trial was conducted within a $9.1 \mathrm{~m}$ by $15.2 \mathrm{~m}$ high tunnel in a randomized complete block design with six replicates in each year. Each plot was $0.9 \times 7.6 \mathrm{~m}$ long with $0.6 \mathrm{~m}$ alleys between plots. The study was identically repeated on the same site in 2017. The two treatments were (i) ASD treatment with dry molasses/soyhull + soybean meal 
TABLE 1 | Amendment nutrient content and application rates in Trials 1, 2, 3, and 4.

\begin{tabular}{|c|c|c|c|c|c|c|c|c|c|c|c|c|c|}
\hline & \multirow[t]{3}{*}{ Crop } & \multirow[t]{3}{*}{ Amendments } & \multirow[t]{3}{*}{ C:N ratio } & \multirow{3}{*}{$\begin{array}{c}\text { Rate of } \\
\text { application } \\
\text { g kg soil }^{-1}\end{array}$} & \multicolumn{9}{|c|}{ Nutrients applied } \\
\hline & & & & & C & $\mathbf{N}$ & $\mathbf{P}$ & $\mathbf{K}$ & $\mathbf{C a}$ & Mg & $\mathbf{S}$ & $\mathrm{Fe}$ & Mn \\
\hline & & & & & \multicolumn{9}{|c|}{$\mathrm{mg} \mathrm{kg}^{-1}$ soil } \\
\hline Trial 1: & Tomato & $\mathrm{DM}^{\dagger}+\mathrm{SM}$ & 10 & $6.4+3.6$ & 4009 & 401.4 & 31.5 & 341.0 & 73.0 & 42.8 & 63.0 & 5.2 & 3.9 \\
\hline Growth chamber/ & & $\mathrm{DM}+\mathrm{SM}$ & 20 & $9.4+0.9$ & 4019 & 201.8 & 15.7 & 402.0 & 87.6 & 46.7 & 74.3 & 6.7 & 4.9 \\
\hline \multirow[t]{6}{*}{ greenhouse study } & & $\mathrm{DM}+\mathrm{CS}$ & 30 & $10.3+0.1$ & 4023 & 133.9 & 9.7 & 416.0 & 91.0 & 47.1 & 76.8 & 7.1 & 5.1 \\
\hline & & $\mathrm{DM}+\mathrm{CS}$ & 40 & $7.7+2.6$ & 4024 & 100.6 & 7.7 & 313.0 & 68.6 & 35.6 & 58.3 & 5.5 & 4.2 \\
\hline & & $W B+S M$ & 10 & $7.8+1.8$ & 4020 & 403.3 & 112.0 & 140.0 & 16.0 & 57.0 & 21.8 & 0.9 & 0.8 \\
\hline & & $W B+C S$ & 20 & $6.4+3.3$ & 3998 & 201.0 & 81.2 & 81.0 & 6.5 & 41.1 & 12.2 & 0.6 & 0.8 \\
\hline & & $W B+C S$ & 30 & $4.2+5.6$ & 4006 & 132.6 & 53.8 & 53.7 & 4.5 & 27.1 & 8.7 & 0.6 & 1.0 \\
\hline & & $W B+C S$ & 40 & $3.2+6.7$ & 4032 & 101.5 & 41.4 & 41.4 & 3.6 & 20.8 & 7.1 & 0.5 & 1.1 \\
\hline Trial 2: & Pepper & $\mathrm{DM}+\mathrm{SM}$ & 10 & $6.4+3.6$ & 3992 & 398.3 & 31.2 & 337 & 72.1 & 42.4 & 62.4 & 3.0 & 0.0 \\
\hline \multirow[t]{4}{*}{ Field study } & & $\mathrm{DM}+\mathrm{SM}$ & 20 & $9.4+0.9$ & 4001 & 200.6 & 11.9 & 277 & 60.2 & 32.7 & 51.3 & 2.2 & 0.0 \\
\hline & & $\mathrm{DM}+\mathrm{CS}$ & 30 & $10.3+0.1$ & 3999 & 133.0 & 9.7 & 413 & 90.7 & 46.8 & 76.5 & 3.7 & 0.0 \\
\hline & & $\mathrm{DM}+\mathrm{CS}$ & 40 & $7.7+2.6$ & 4007 & 100.3 & 7.4 & 309 & 67.6 & 34.9 & 57.2 & 3.0 & 0.0 \\
\hline & & LC (DM + SM) & 30 & $5.1+0.04$ & 2002 & 70.6 & 4.5 & 207 & 45.3 & 23.0 & 37.9 & 1.5 & 0.0 \\
\hline Trial 3: & Tomato & $\mathrm{DM}^{\star}+\mathrm{SM}+$ Compost & 12 & $9.5+0.9+9.8$ & 7248 & 620.8 & 71.1 & 414 & 234.7 & 118.2 & 75.5 & 164.1 & 6.0 \\
\hline $\begin{array}{l}\text { On farm high } \\
\text { tunnel study }\end{array}$ & & Compost/Control & 14 & 9.8 & 3204 & 230.8 & 58.8 & 132 & 173.6 & 85.3 & 23.5 & 161.8 & 5.9 \\
\hline Trial 4: & Pepper/ Eggplant & $\mathrm{Suc}+\mathrm{FM}$ & 34 & $7.2+0.7$ & 3365 & 98.5 & 1.4 & 0.7 & 3.2 & 0.3 & 9.0 & 0.1 & 0.0 \\
\hline \multirow[t]{3}{*}{ High tunnel study } & & $\mathrm{CS}^{*}+\mathrm{FM}$ & 30 & $7.6+0.7$ & 3415 & 114.0 & 2.6 & 1.1 & 3.8 & 0.5 & 11.3 & 0.2 & 0.0 \\
\hline & & $P S+F M$ & 27 & $6.2+0.7$ & 3287 & 120.9 & 15.2 & 6.0 & 35.4 & 3.0 & 99.0 & 1.1 & 0.1 \\
\hline & & FM/Control & 3 & 0.3 & 161 & 54.2 & 0.8 & 0.3 & 1.7 & 0.1 & 4.9 & 0.1 & 0.0 \\
\hline
\end{tabular}

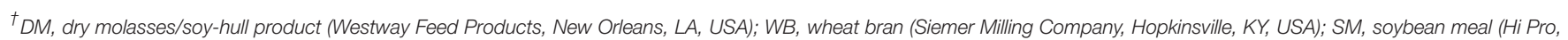

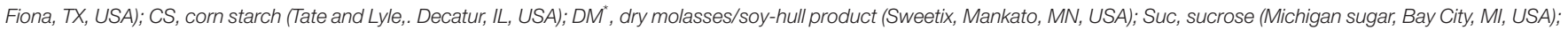
$\mathrm{CS}^{*}$, corn starch (Ingerdion Inc, Westchester, IL, USA), PS, pine shavings (America's Choice, Columbia, MD, USA); FM, feather meal (Mason City By-Products, Mason City, IA, USA).

amendment (20:1 C:N ratio, $4 \mathrm{mg} \mathrm{C} \mathrm{g}^{-1}$ soil) + compost, and ii) a standard practice treatment (compost amendment only at $1.31 \mathrm{~kg}$ dry matter $\mathrm{m}^{-2}$ ) (Table 1). The ASD amendments and $\mathrm{C}: \mathrm{N}$ ratio were chosen based on crop performance and inoculated pathogen mortality assessments in previous trials (Shrestha et al., 2018a, 2021). Prior to treatment, five $0-15 \mathrm{~cm}$ soil cores were collected from each plot. Amendment and compost samples were composited and analyzed for nutrient content as for ASD amendments in Trial 1 (Table 1). Amendments and compost were incorporated into plots using a rotovator to $\sim 15$-cm depth. After incorporating amendments, plots were mulched with black polyethylene $(0.032 \mathrm{~mm})$ and drip irrigation installed. Plots were irrigated with $5-\mathrm{cm}$ of water to ensure saturation to $\sim 20-\mathrm{cm}$ depth. All plots were equipped with ORE and combination soil temperature/moisture sensors (5TM Soil Moisture and Temperature Probe, Decagon Devices, Pullman, WA, USA). Five $0-15 \mathrm{~cm}$ soil cores from each plot were collected at $7,14,21$, and 32 days from treatment initiation. The core samples from each plot were composited and then used to evaluate soil $\mathrm{pH}$ and soil inorganic $\mathrm{N}$ as described in trial 1.

After 4 weeks of treatment incubation, three tomato cultivars (cvs. Sungold, Cherokee Purple and Valencia) were transplanted (16 plants per plot; $45-\mathrm{cm}$ spacing) with each block planted to a single cultivar (two blocks per cultivar). Crop performance and leaf $\mathrm{N}$ were assessed as described in Trial 2. Total marketable tomato fruit yield data was collected 2-3 times each week from mid-June to mid-July.

\section{Trial 4. ASD Amendment Substrate Bioavailability Effects on Soil Nutrients and Bell Pepper and Eggplant Performance}

Experiments were established in two separate high tunnels at the University of Tennessee, Organic Crops Unit in Knoxville, TN, USA in spring 2016 to evaluate ASD amendment bioavailability effects on soil inorganic N, bell pepper and eggplant (Solanum melongena L.) leaf tissue $\mathrm{N}$ and crop yield. The experimental details are provided in Shrestha et al. (2020a) and ASD treatments included a range of amendments based on substrate bioavailability (sucrose, corn starch, pine shavings, each with feather meal added to bring to a $\sim 30: 1 \mathrm{C}: \mathrm{N}$ amendment $\mathrm{C}: \mathrm{N}$ ratio and $\sim 3.4 \mathrm{mg} \mathrm{C} \mathrm{g}^{-1}$ soil) which were compared to an anaerobic control with feather meal amendment only (Table 1). The design of the experiment was a split plot randomized complete block design with six replicates. Crop (bell pepper or eggplant) was assigned as the whole plot and soil treatments (ASD treatments or control) as the split plot. Each high tunnel had six beds of length $12.2 \times 1.22 \mathrm{~m}$ each, which were divided into four 
plots receiving split-plot treatments at $3 \times 0.6 \mathrm{~m}$. The soil type according to the USDA classification system was a Dewey silt loam (fine, kaolinitic, thermic, Typic Paleudult). Treatments were established as described in other trials with irrigation supplied over $12 \mathrm{~h}$ through drip irrigation to fill soil pore space to an approximate $20-\mathrm{cm}$ depth. IRIS tubes and ORE were inserted in each treatment on three beds of each high tunnel to determine anaerobic conditions, and soil samples collected from each plot as described previously.

Bell pepper (cv. Sweet Sunrise) and eggplant (cv. Traviata) were randomly assigned to whole plots and transplanted after 3 weeks of ASD treatment. Pepper transplants were planted double row per bed at 30-cm spacing. Eggplant transplants were planted in a single row with $45-\mathrm{cm}$ spacing. Plants were harvested five times from mid-July to mid-August for bell pepper (at mature, yellow color) and seven times from late-June to mid-August for eggplant. End of row plants in each treatment were excluded and harvests were graded using standard USDA fruit grading as described previously. Pepper and eggplant leaf tissue from high tunnels were collected as described previously to evaluate leaf $\mathrm{N}$ for both crops.

\section{Statistical Analysis}

A mixed model analysis of variance was conducted with SAS (9.3 SAS Institute, Cary, NC, USA) for each trial; data were checked for normality and homogeneity of variances and transformed as needed (log or rank transformation). For trial 1, amendment type, amendment C:N ratio were considered fixed effects and trial was treated as a random effect, and a two-way factorial analysis between $\mathrm{C}$ amendment and C:N ratio performed. Data were also analyzed separately by $\mathrm{C}$ amendment to compare treatments with the anaerobic control and also by $\mathrm{C}: \mathrm{N}$ ratios to compare with the anaerobic control. For field and high tunnel studies (trials 2, 3, 4) soil treatment was considered the fixed effect and block and year (or tunnel in trial 4) were considered random effects. Soil pH in trial 3 was analyzed separately by treatment and time points. Least squares means were compared with Fisher's P-LSD at 5\% significance level and untransformed means and standard errors are reported. Relationships of crop yield (or biomass for trial 1) with soil inorganic $\mathrm{N}$ and leaf $\mathrm{N}$ were assessed for each trial with Pearson or Spearman correlation analysis at $P<0.05$.

\section{RESULTS}

\section{Soil Characteristics}

Data for soil $\mathrm{pH}$ and soil anaerobic conditions for trials 1, 2 and 4 have been published previously (Shrestha et al., 2018a, 2020a). Here we summarize the overall results briefly to provide an overview of the environmental conditions during soil treatments (see Supplementary Table 1). There was no significant effect of ASD treatments on soil $\mathrm{pH}$ measured after ASD termination and/or during cropping phase for all studies except trial 1 (pot study) where the lowest $\mathrm{pH}$ of 5.1 was observed at ASD amendment C:N ratio of 10:1 for both amendment types, whereas for all other treatments soil $\mathrm{pH}$ ranged from 5.3 to 5.4. In trial 2 (field study) soil $\mathrm{pH}$ at ASD termination ranged from 5.8 to 6.0, and later during the cropping period increased by 0.1 to 0.3
$\mathrm{pH}$ units. Both high tunnel study (trials 3, 4) sites had higher soil $\mathrm{pH}$ than other studies, ranging from 6.9 to 7.3 (data not shown), which can be typical in protected culture systems in the region, largely due to lack of leaching rainfall under plastic cover and different amendment and irrigation rates and strategies than in open-field production systems (Knewtson et al., 2012). Soil $\mathrm{pH}$ taken in a series of sampling time points in trial 3 showed increases in soil pH during ASD incubation, which then trended downwards during the cropping phase regardless of treatment (Figure 1).

Accumulated soil anaerobic conditions were higher in all ASD treatments compared to their respective controls in all trials. For trial 1 (growth chamber/greenhouse studies) the more anaerobic condition was generated in dry molasses/soy hull amended treatments (190 to $234 \mathrm{~V} \mathrm{~h}$ ) and wheat bran amended treatment (166 to $194 \mathrm{~V} \mathrm{~h}$ ) compared to anaerobic controls $(106 \mathrm{~V} \mathrm{~h})$. In trial 2, although accumulated anaerobic conditions (173-201 V h) trended higher in all ASD treatments amended at $4 \mathrm{mg} \mathrm{C} \mathrm{g}^{-1}$ soil when compared to ASD at $2 \mathrm{mg}$ $\mathrm{C}^{-1}$ soil and the anaerobic control, this comparison was not statistically significant due to a limited number of replicates for this measure. However, there were significant treatment effects on the percentage of iron oxyhydroxide reduction observed. The percentage of oxyhydroxide paint removal was higher in all ASD treatments at $4 \mathrm{mg} \mathrm{C} \mathrm{g}^{-1}$ soil amendment rates (31 to $35 \% \mathrm{Fe}$ solubilization) than in the reduced amendment rate treatment (17.5\% Fe solubilization) and anaerobic control (8.6\% Fe solubilization). Similar results were observed in trial 3 with higher accumulated anaerobic conditions observed for ASD $(136 \mathrm{~V} \mathrm{~h})$ than the compost-only control $(15 \mathrm{~V} \mathrm{~h})$ and for trial 4, ASD treatment with more bioavailable substrates (sucrose, corn starch) had more anaerobic soil conditions (127 and $67 \mathrm{~V} \mathrm{~h}$, respectively) than less bioavailable substrate (pine shavings, $18 \mathrm{~V} \mathrm{~h}$ ) or the feather meal-only control (7 V h). Similar differences among treatments were observed for the percentage of oxyhydroxide paint removal (Supplementary Table 1).

\section{Effect of ASD Treatment on Soil and Plant N}

Soil Inorganic $\mathbf{N}$

Soil inorganic $\mathrm{N}\left(\mathrm{NH}_{4}-\mathrm{N}, \mathrm{NO}_{2}-\mathrm{N}+\mathrm{NO}_{3}-\mathrm{N}\right)$ measured at the termination of ASD treatment was significantly affected by ASD amendment and amendment $\mathrm{C}: \mathrm{N}$ ratio in trial 1 (Table 2), amendment $\mathrm{C}: \mathrm{N}$ ratio and amendment $\mathrm{C}$ rate in trial 2, by soil treatment in trial 3, and by soil treatment in trial 4 (Table 3). Soil inorganic $\mathrm{N}$ during the cropping phase was also significantly affected by treatments for all studies where evaluated (trials 1,2 , and 3 ).

For trial 1, no significant interaction effect of ASD amendment and amendment C:N ratio was observed on total soil inorganic $\mathrm{N}$ at termination of ASD treatment (Table 2). Soil inorganic $\mathrm{N}$ at ASD termination was primarily $\mathrm{NO}_{2}-\mathrm{N}+\mathrm{NO}_{3}-\mathrm{N}$ (72 to $92 \%$ of total inorganic $\mathrm{N}$ ) at ASD termination, with lower $\mathrm{NH}_{4}-\mathrm{N}(8$ to $28 \%$ of total inorganic $\mathrm{N}$ ), indicating sufficient soil oxidation allowing for nitrification of mineralized $\mathrm{N}$ by the termination of ASD treatments. Among C:N ratios, the highest mean soil 


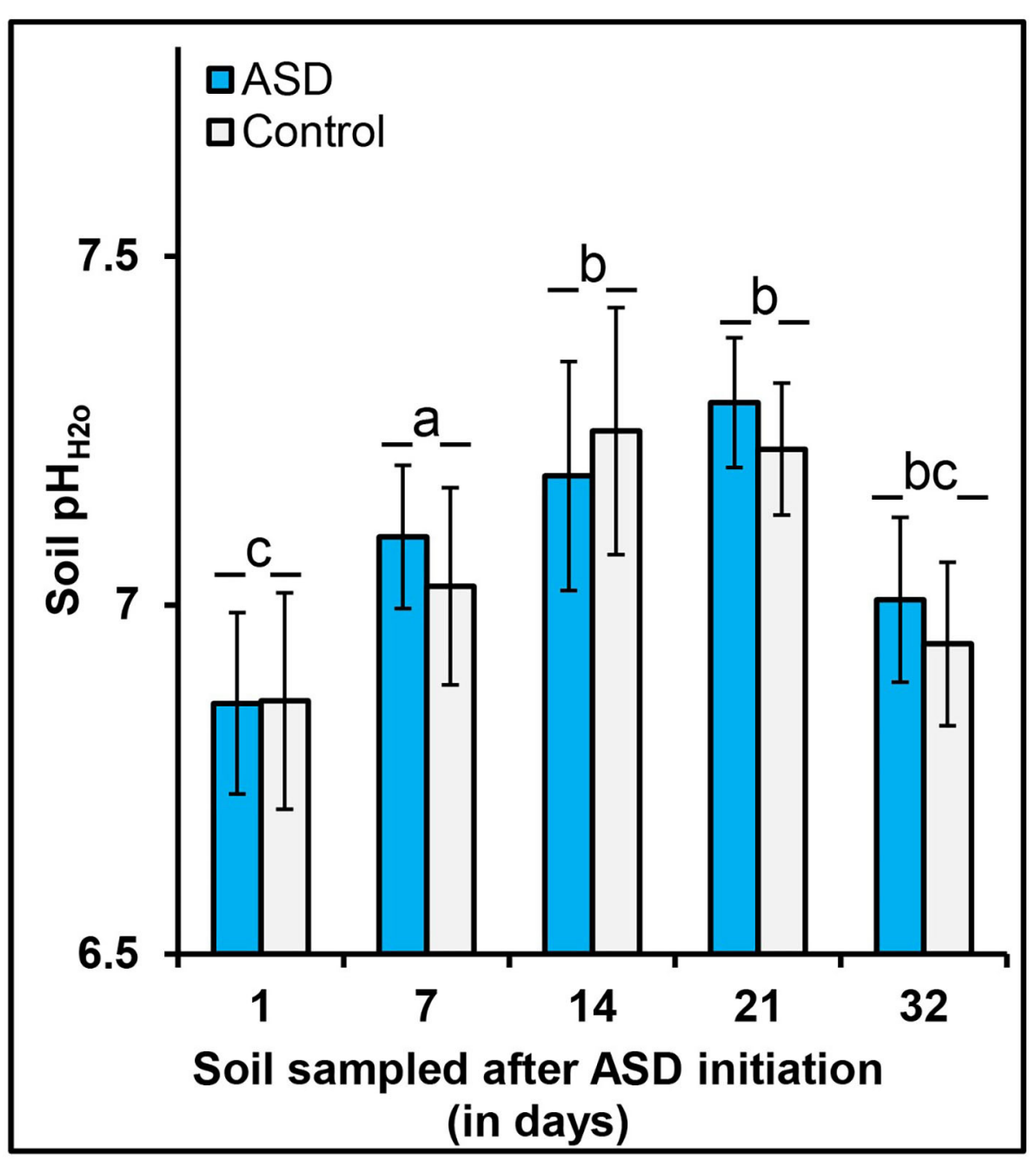

FIGURE 1 | Effect of ASD treatment and sampling time on soil $\mathrm{pH}$, high tunnel, trial 3. Bars indicated by similar letters for sampling time are not significantly different at $P<0.05$ according to Fisher's protected LSD test. Error bars indicate standard error with 12 total replicates (6 replicates $\times 2$ experiments).

TABLE 2 | Main effect of ASD amendment and analysis of variance for soil nitrogen response variables after ASD and/or during cropping phase as affected by soil treatment in trial 1.

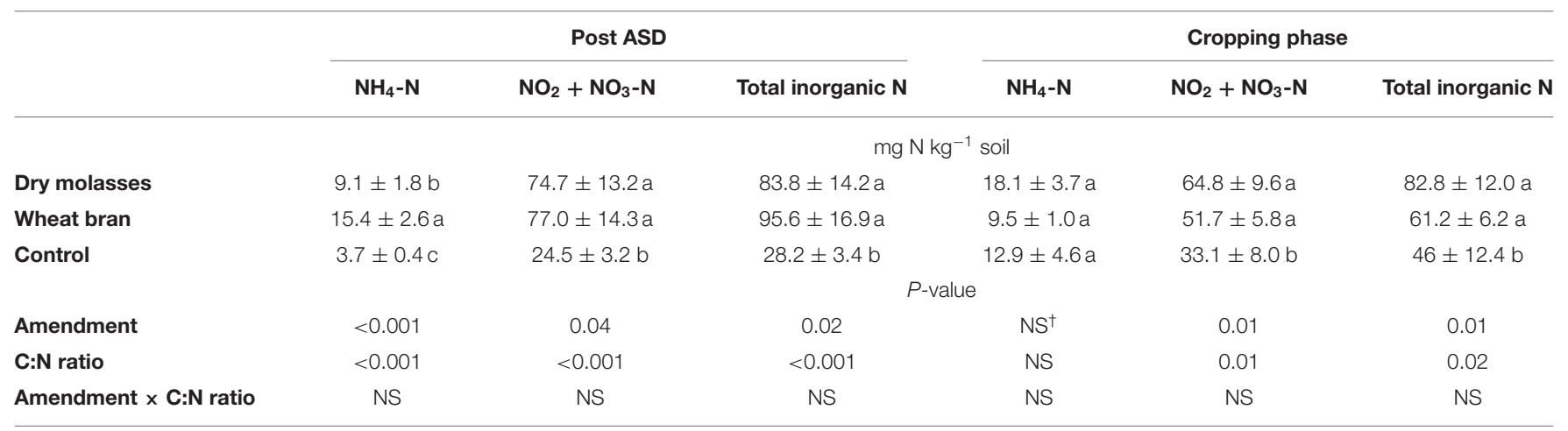

${ }^{\dagger}$ NS, not significant; $P>0.05$.

Values represent means and standard errors of 8 total replicates ( 4 replicates $\times 2$ experiments). 


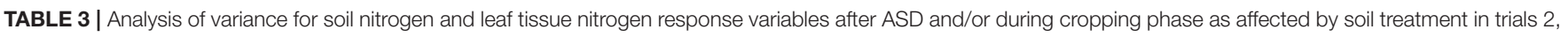
3 and 4.

\begin{tabular}{|c|c|c|c|c|c|c|c|}
\hline & \multicolumn{3}{|c|}{ Post ASD } & \multicolumn{4}{|c|}{ Cropping phase } \\
\hline & $\mathrm{NH}_{4}-\mathrm{N}$ & $\mathrm{NO}_{2}+\mathrm{NO}_{3}-\mathrm{N}$ & Total inorganic $\mathbf{N}$ & $\mathrm{NH}_{4}-\mathrm{N}$ & $\mathrm{NO}_{2}+\mathrm{NO}_{3}-\mathrm{N}$ & Total inorganic $\mathbf{N}$ & Leaf tissue $\mathrm{N}$ \\
\hline & \multicolumn{7}{|c|}{$P$-value } \\
\hline Trial 2: Field study & $<0.001$ & $<0.001$ & $<0.001$ & 0.04 & $<0.001$ & $<0.001$ & $<0.001$ \\
\hline Trial 3: On farm high tunnel study & 0.002 & $\mathrm{NS}^{\dagger}$ & NS & NS & 0.003 & 0.003 & NS \\
\hline Trial 4: High tunnel study & NS & $<0.001$ & $<0.001$ & $N / A^{\ddagger}$ & $\mathrm{N} / \mathrm{A}$ & $\mathrm{N} / \mathrm{A}$ & N/A \\
\hline
\end{tabular}

${ }^{\dagger} N S$, not significant; $P>0.05 ;{ }^{\ddagger} N / A$, not applicable, was not evaluated in trial 4 .

inorganic $\mathrm{N}$ was observed at C:N ratio of 10:1 (212 $\mathrm{mg} \mathrm{N} \mathrm{kg}^{-1}$ soil; Figure 2A), and among amendments the highest total soil inorganic $\mathrm{N}$ was observed for wheat bran-based $(241.0 \mathrm{mg} \mathrm{N}$ $\mathrm{kg}^{-1}$ soil for C:N 10:1, 9 times higher than control) followed by dry molasses/soy hull-based (181.9 $\mathrm{mg} \mathrm{N} \mathrm{kg}^{-1}$ soil for C:N 10:1, 6 times higher than the control). The anaerobic control had the least amount of total inorganic $\mathrm{N}$ at the time of ASD treatment termination (28.2 $\mathrm{mg} \mathrm{N} \mathrm{kg}^{-1}$ soil; Figure $2 \mathrm{~A}$ ). During the cropping phase, soil $\mathrm{NO}_{2}-\mathrm{N}+\mathrm{NO}_{3}-\mathrm{N}$ was highest at $\mathrm{C}: \mathrm{N}$ ratios of 10:1 and 20:1 (>60 mg $\mathrm{NO}_{2}-\mathrm{N}+\mathrm{NO}_{3}-\mathrm{N} \mathrm{kg}^{-1}$ soil) and total soil inorganic $\mathrm{N}$ was similarly higher than the control only at C:N ratios of 10:1 and 20:1 when compared to the control (Figure 2B). There was no significant effect of ASD amendment or amendment $\mathrm{C}: \mathrm{N}$ ratio on soil $\mathrm{NH}_{4}-\mathrm{N}$ during the cropping phase (Table 2).

Prior to ASD treatment in trial 2, total soil inorganic $\mathrm{N}$ ranged from 5.7 to $7 \mathrm{mg} \mathrm{N} / \mathrm{kg}$ of soil (3 to $4.7 \mathrm{mg} \mathrm{NH} \mathrm{NH}_{4}-\mathrm{N}$ $\mathrm{kg}^{-1}$ soil and 1.9 to $2.8 \mathrm{mg} \mathrm{NO}_{2}-\mathrm{N}+\mathrm{NO}_{3}-\mathrm{N} \mathrm{kg}^{-1}$ soil). As in trial 1, dry molasses/soy hull-based amendments at the 10:1 C: $\mathrm{N}$ ratio significantly increased soil total inorganic $\mathrm{N}$ (63.3 mg N kg-1 soil), soil $\mathrm{NO}_{2}-\mathrm{N}+\mathrm{NO}_{3}-\mathrm{N}(27.7 \mathrm{mg} \mathrm{NO}-\mathrm{N}$ $+\mathrm{NO}_{3}-\mathrm{N} \mathrm{kg}^{-1}$ soil) and $\mathrm{NH}_{4}-\mathrm{N}\left(35.4 \mathrm{mg} \mathrm{NH}_{4}-\mathrm{N} \mathrm{kg}^{-1}\right.$ soil) at the termination of ASD treatment (Figure 3A). The fumigated treatment and the ASD treatment at the 20:1 amendment C:N ratio had intermediate total inorganic $\mathrm{N}$ (17 $\mathrm{mg} \mathrm{N} \mathrm{kg}^{-1}$ soil) and the total inorganic $\mathrm{N}$ was similar at all other ASD/C:N ratio treatments and the anaerobic control $\left(9.1 \mathrm{mg} \mathrm{N} \mathrm{kg}^{-1}\right.$ soil; Figure 3A). However, during the cropping phase with equal fertigation management, higher soil inorganic $\mathrm{N}$ was observed at all ASD treatments except for the reduced amendment rate when compared to control and fumigated treatments (Figure 3B). This was especially the case at the 10:1 amendment C:N ratio, where total inorganic $\mathrm{N}$ was five-fold higher than the fumigated or anaerobic controls, whereas at 20:1 to 40:1 C:N ratios total inorganic $\mathrm{N}$ was only two-fold higher than the controls.

In trial 3, ASD treatment increased total soil inorganic $\mathrm{N}$ as the incubation period progressed and was significantly higher than the compost-only control at 2 to 3 weeks post treatment termination (Figure 4). During the ASD incubation period, soil $\mathrm{NH}_{4}-\mathrm{N}$ was significantly higher in the ASD treatment at 2 weeks ( 4.8 vs. $3.5 \mathrm{mg} \mathrm{NH}_{4}-\mathrm{N} \mathrm{kg}^{-1}$ soil) and 3 weeks (6.3 vs. $4.9 \mathrm{mg} \mathrm{NH}_{4}-\mathrm{N} \mathrm{kg}^{-1}$ soil, Table 3 ) compared to the compost-only control (Figure 4). There was no significant difference among treatments in soil inorganic $\mathrm{N}$ during the 1st week of treatment incubation (Table 3). At the end of ASD treatment incubation in trial 4, ASD treatments amended with pine shavings + feather meal had the highest total inorganic $\mathrm{N}\left(116.0 \mathrm{mg} \mathrm{N} \mathrm{kg}^{-1}\right.$ soil; primarily $\left.\mathrm{NO}_{2}-\mathrm{N}+\mathrm{NO}_{3}-\mathrm{N}\right)$, the feather meal-only control was intermediate ( $83.0 \mathrm{mg} \mathrm{N} \mathrm{kg}^{-1}$ soil), and total soil inorganic $\mathrm{N}$ was lowest from the ASD treatments amended with sucrose + feather meal or corn starch + feather meal (44.5-55.7 $\mathrm{mg} \mathrm{N} \mathrm{kg}^{-1}$ soil; Figure 5).

\section{Leaf/Shoot Tissue $\mathbf{N}$ and Correlation With Soil $\mathbf{N}$}

In trial 1, there was no significant correlation between plant tissue $\mathrm{N}$ and soil inorganic $\mathrm{N}$ during ASD termination or the cropping phase (Table 4). Tomato shoot tissue $\mathrm{N}$ was significantly affected by the main effect of ASD amendment, but not amendment $\mathrm{C}: \mathrm{N}$ ratio or the interaction between the ASD amendment and ASD amendment C:N ratio (Table 5). Wheat bran-based ASD amendments, averaged across C:N ratios, had the highest shoot tissue $\mathrm{N}\left(36.9 \mathrm{mg} \mathrm{N} \mathrm{g}^{-1}\right)$ compared to dry molasses/soyhull-based amendments and the control (27.8$28.7 \mathrm{mg} \mathrm{N} \mathrm{g}^{-1}$; Table 5).

In trial 2, bell pepper leaf tissue $\mathrm{N}$ was positively correlated with soil $\mathrm{NH}_{4}-\mathrm{N}$ and total soil inorganic $\mathrm{N}(0.3, P<0.05)$ and significantly affected by soil treatments $(P<0.001$, Table 4$)$. Among treatments, there was a higher leaf tissue $\mathrm{N}$ concentration from treatments with low C:N ratio ASD amendments (e.g., $10: 1,57.1 \mathrm{mg} \mathrm{N}^{-1}$ ) than high $\mathrm{C}: \mathrm{N}$ ratio ASD amendments (e.g., 40:1, $50.5 \mathrm{mg} \mathrm{N} \mathrm{g}^{-1}$; Figure 6A). The lowest leaf tissue $\mathrm{N}$ was observed in the low carbon rate amendment treatment (30:1 C: $\mathrm{N}$ ratio, $48.7 \mathrm{mg} \mathrm{N} \mathrm{kg}^{-1}$ ). Leaf tissue $\mathrm{N}$ in the fumigated treatment and anaerobic control treatment was intermediate (51.6-54.9 $\mathrm{mg} \mathrm{N} \mathrm{kg}^{-1}$ ), and the fumigated treatment did not differ from any ASD treatment at the $4 \mathrm{mg} \mathrm{C} \mathrm{g}^{-1}$ soil amendment rate (Figure 6A).

In the on-farm high tunnel trial (trial 3), tomato leaf tissue $\mathrm{N}$ did not differ in the ASD treatment $\left(53.5 \mathrm{mg} \mathrm{N} \mathrm{g}^{-1}\right.$ ) compared to the compost-only control (51.5 $\mathrm{mg} \mathrm{N} \mathrm{g}^{-1}$; Figure 6B). Similarly, in the research farm high tunnel trial (trial 4) ASD amendments of sucrose + feather meal $\left(36.8 \mathrm{mg} \mathrm{N} \mathrm{g}^{-1}\right)$ and pine shavings + feather meal (38.2 $\mathrm{mg} \mathrm{N} \mathrm{g}^{-1}$ ) had similar leaf tissue $\mathrm{N}$ compared to corn starch + feather meal and the feather meal only control (40.2-42.0 $\mathrm{mg} \mathrm{N} \mathrm{g}^{-1}$; Figure 6C). For eggplant leaf tissue $\mathrm{N}$, no differences were observed among amendments with leaf tissue concentrations ranging from 44.2 to $46.8 \mathrm{mg} \mathrm{N}$ $\mathrm{g}^{-1}$ for all treatments (Figure 6D). A significant, but moderate positive relationship of leaf tissue $\mathrm{N}$ with post-ASD soil $\mathrm{NH}_{4}{ }^{-}$ $\mathrm{N}$ was observed in trial 3 with tomato $(0.4, P<0.05)$ and in 


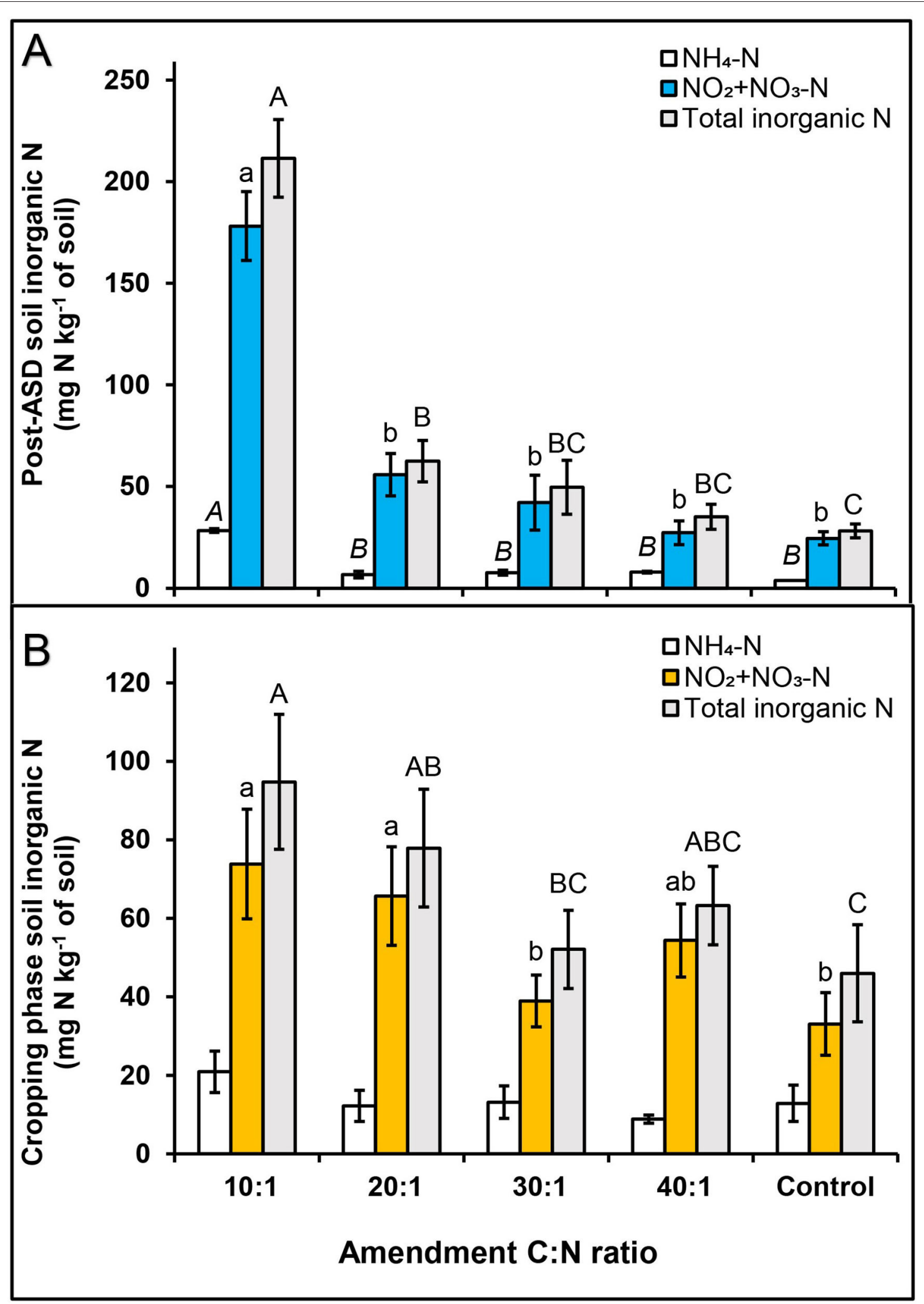

FIGURE 2 | Effect of ASD amendment C:N ratio across amendment types (dry molasses/soybean hull-based and wheat bran-based) on soil inorganic $\mathrm{N}$ at (A) post-ASD treatment and (B) during cropping phase, trial 1. Bars indicated by similar letters for each category are not significantly different at $P<0.05$ according to Fisher's protected LSD test. Error bars indicate standard error with eight total replicates ( 4 replicates $\times 2$ experiments). Control $=$ anaerobic, non-amended control. 


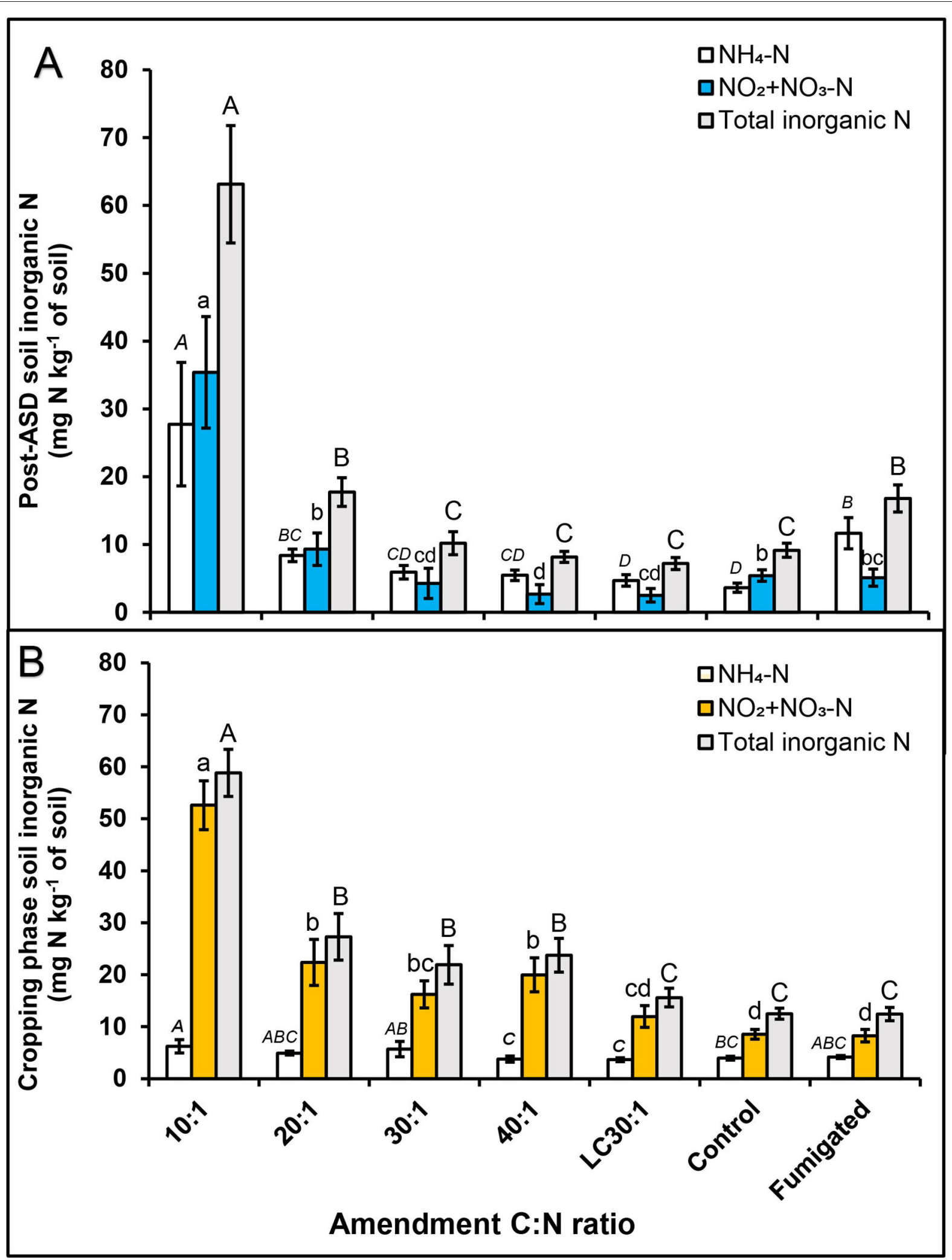

FIGURE 3 | Effect of dry molasses/soybean hull-based ASD amendment C:N ratio on soil inorganic N, (A) post-ASD treatment and (B) during cropping phase, trial 2. Bars indicated by similar letters for each category are not significantly different at $P<0.05$ according to Fisher's protected LSD test. Error bars indicate standard error with eight total replicates ( 4 replicates $\times 2$ experiments). $\mathrm{LC}=$ Low carbon, Control $=$ anaerobic, non-amended control, Fumigated $=$ methyl bromide $(\mathrm{MeBr})$ fumigated control (67:33 mixture with chloropicrin, $\left.224 \mathrm{~kg} \mathrm{ha}^{-1}\right)$. 


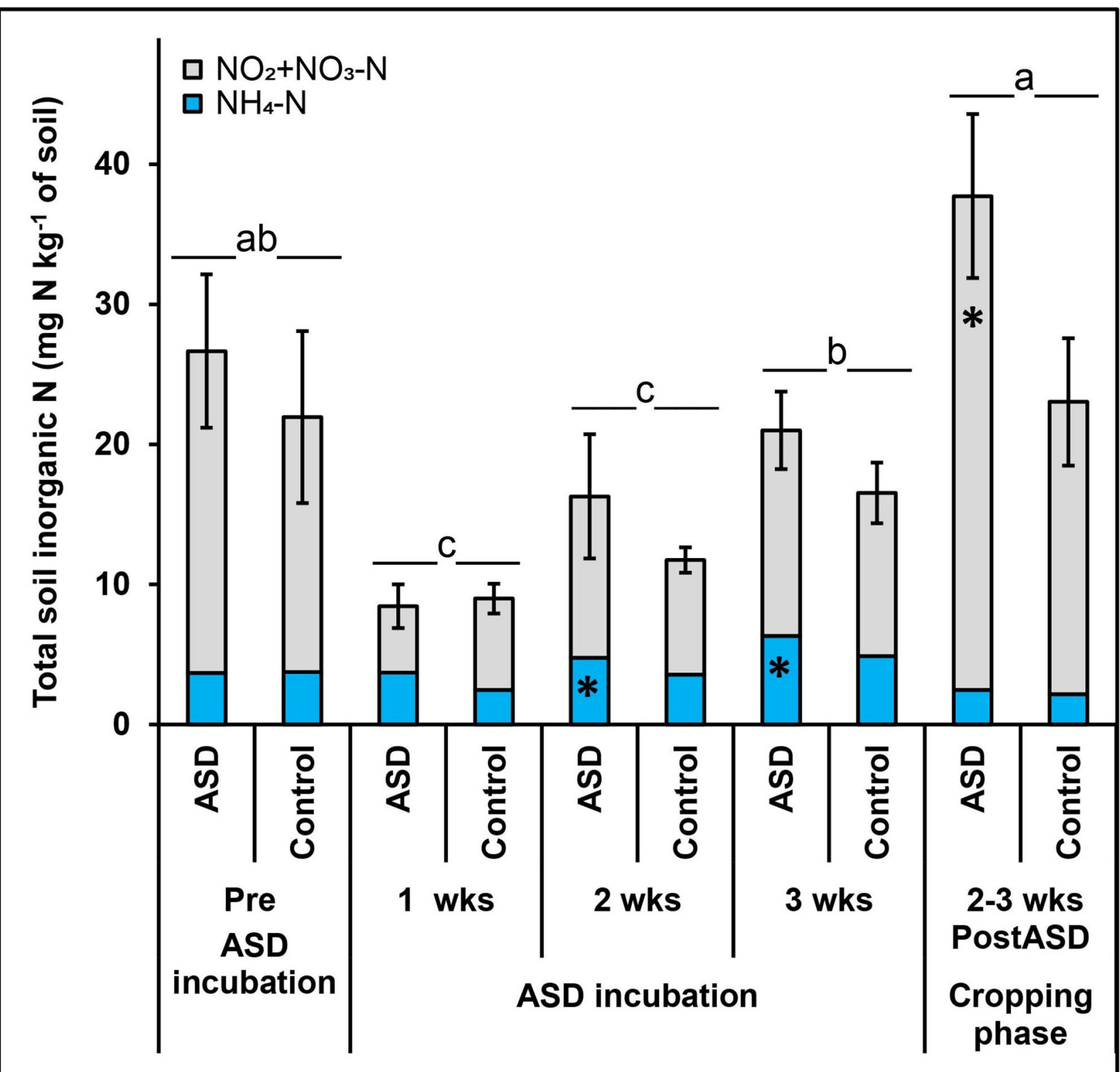

FIGURE 4 | Effect of ASD on soil inorganic N post-ASD treatment high tunnel study, trial 3 . Bars indicated by similar letters for each category are not significantly different at $P<0.05$ according to Fisher's protected LSD test and means indicated by * are significantly different from the control. Error bars indicate standard error with twelve total replicates ( 6 replicates $\times 2$ experiments). Control $=$ anaerobic, compost-amended control.

trial 4 with bell pepper $(0.5, P<0.01)$. Eggplant leaf tissue $\mathrm{N}$ in trial 4 correlated moderately and positively with postASD soil $\mathrm{NO}_{2}-\mathrm{N}+\mathrm{NO}_{3}-\mathrm{N}$ and total soil inorganic $\mathrm{N}(0.4$, $P<0.05$, Table 4).

\section{Crop Performance and Correlation to Soil and Leaf Tissue $\mathbf{N}$}

Tomato plant growth in trial 1 was significantly affected by ASD amendment and amendment $\mathrm{C}: \mathrm{N}$ ratio without any interaction (Table 5). Fruit yield and dry shoot biomass was higher in treatments with dry molasses/soy hull-based ASD amendments (57 $\mathrm{g}$ fruit plant $^{-1}$ and $51 \mathrm{~g}$ dry biomass plant ${ }^{-1}$, respectively) compared to the wheat bran-based ASD amendments (37 and $42 \mathrm{~g} \mathrm{plant}^{-1}$, respectively) and the non-amended control (20 and 38 g plant $^{-1}$, respectively; Table 5). Among C:N ratios, the highest mean fruit weight, root and shoot biomass were observed at C:N ratio of 10:1 (Table 5).

In trial 2, the total number of bell pepper fruit per plant was significantly higher in ASD treatments with lower C:N ratios (10 and 20:1), compared to fumigated and anaerobic control treatments. However, this difference was only observed in the 


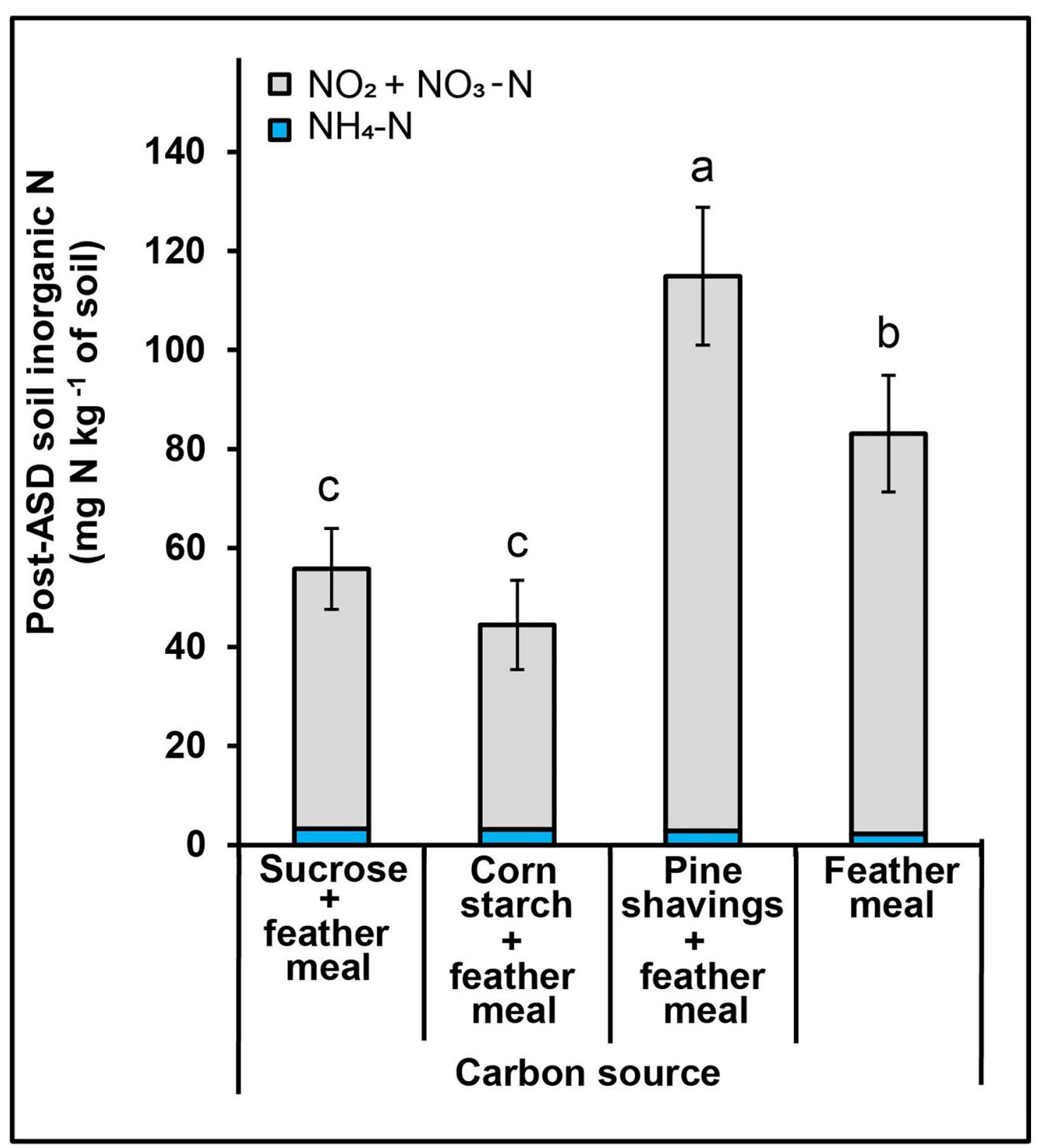

FIGURE 5 | Effect of ASD amendment (various C substrate) on soil inorganic N post-ASD treatment high tunnel study, trial 4. Bars indicated by similar letters are not significantly different at $P<0.05$ according to Fisher's protected LSD test. Error bars indicate standard error with twelve replicates.

2014 season (data not shown). Marketable yield (30 to $35 \mathrm{Mg}$ $\mathrm{ha}^{-1}$ ) and fancy-grade yield ( 11.3 to $15.7 \mathrm{Mg} \mathrm{ha}^{-1}$ ) was higher across both years in all ASD treatments amended at $4 \mathrm{mg} \mathrm{C} \mathrm{g}^{-1}$ soil, and lowest in fumigated and anaerobic control treatments (marketable, 20 to $24 \mathrm{Mg} \mathrm{ha}^{-1}$ and fancy-grade, $4.4 \mathrm{Mg} \mathrm{ha}^{-1}$; Figure 6A). Similarly, total fruit yield (marketable + culled fruits) was highest in ASD treatments at 10, 20 and 30:1 ASD amendment C: $\mathrm{N}$ ratios (at $4 \mathrm{mg} \mathrm{C} \mathrm{g}^{-1}$ soil; 33.9 to $39.2 \mathrm{Mg} \mathrm{ha}^{-1}$ ), and lowest in fumigated $\left(25.2 \mathrm{Mg} \mathrm{ha}^{-1}\right)$ and anaerobic control treatments $\left(29.3 \mathrm{Mg} \mathrm{ha}^{-1}\right)$.
In trial 3 , the number of tomato fruit per meter of row was increased by $21 \%$ in ASD treatment $\left(8.1 \mathrm{~kg} \mathrm{~m}^{-1}\right)$ compared to the compost-amended control treatment $\left(6.7 \mathrm{~kg}\right.$ fruit $\mathrm{m}^{-1}$; Figure 6B). In trial 4 , the highest fancy-grade bell pepper yield among treatments was observed for corn starch + feather meal ASD treatment $\left(6 \mathrm{~kg} \mathrm{~m}^{-1}\right)$, however, this was not significantly higher than the feather meal only control (Figure 6C). Similarly, eggplant yield did not differ significantly among treatments and ranged from $7.3 \mathrm{~kg} \mathrm{~m}^{-1}$ in the sucrose + feather meal ASD treatment to a low of $6.2 \mathrm{~kg} \mathrm{~m}^{-1}$ in the feather meal only control 
TABLE 4 | Correlation analysis of crop performance variables and soil and leaf tissue $\mathrm{N}$ in each trial.

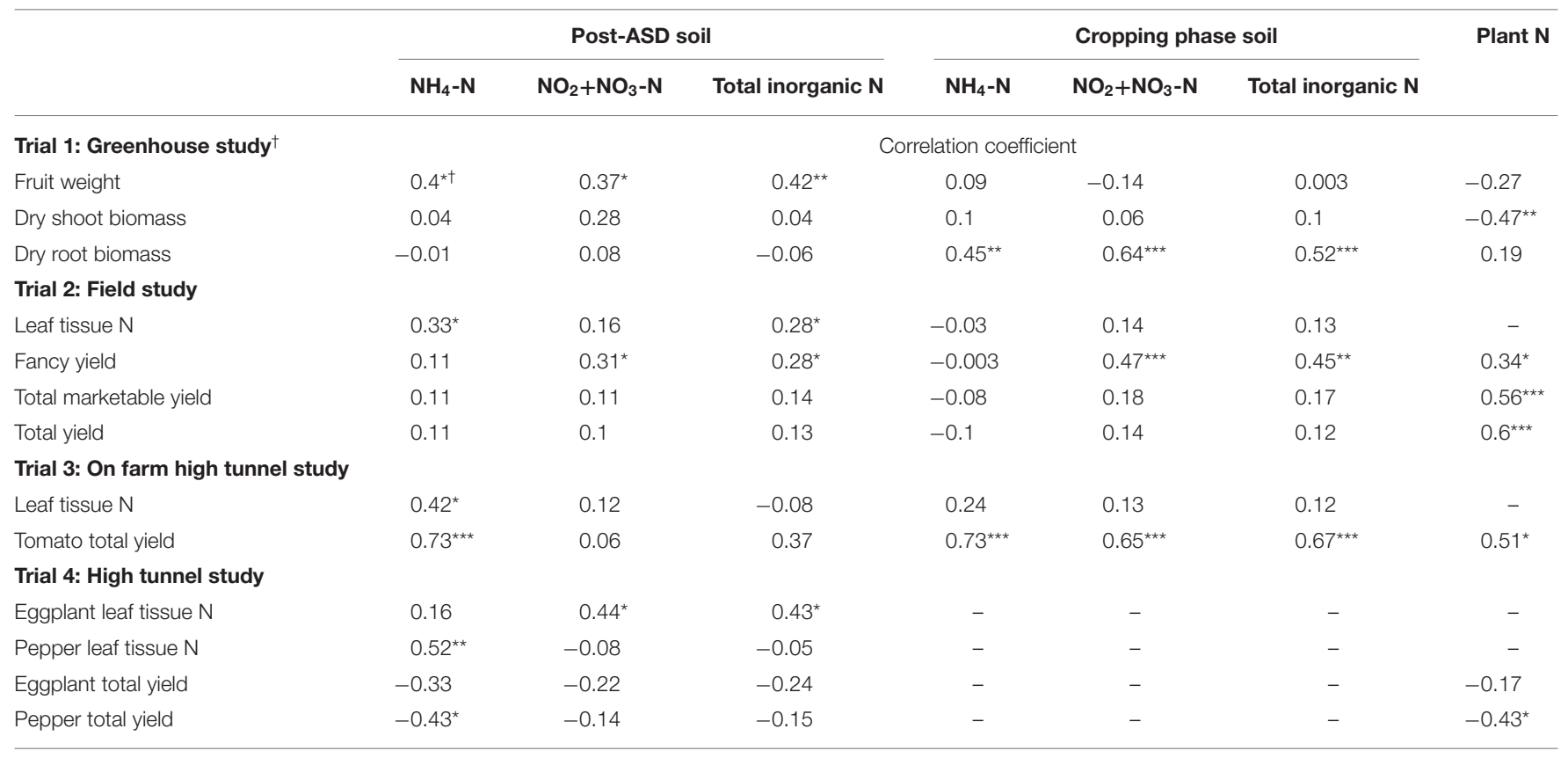

${ }^{\dagger}$ Each row within each variable represents Pearson or Spearman correlation coefficients. Correlation is significant at ${ }^{*} P<0.05,{ }^{* *} P<0.01$, and ${ }^{\star * *} P<0.001$. Correlation coefficients without * are non-significant at $P>0.05$.

TABLE 5 | Mean values by main effects and analysis of variance for growth characteristics tomato plant 8-week post termination of ASD treatment as affected by carbon amendment, $\mathrm{C}: \mathrm{N}$ ratio and the interaction in trial 1.

\begin{tabular}{|c|c|c|c|c|c|}
\hline $\begin{array}{l}\text { Shoot N } \\
\left(\mathrm{mg} \mathrm{N} \mathrm{g}^{-1}\right)\end{array}$ & $\begin{array}{c}\text { Fruit weight } \\
\left.\text { (g plant }^{-1}\right)\end{array}$ & $\begin{array}{l}\text { Fruit number } \\
\text { (fruit plant }^{-1} \text { ) }\end{array}$ & $\begin{array}{l}\text { Shoot height } \\
\text { (cm) }\end{array}$ & $\begin{array}{l}\text { Dry shoot } \\
\text { biomass } \\
\text { (g plant }^{-1} \text { ) }\end{array}$ & $\begin{array}{c}\text { Dry root } \\
\text { biomass } \\
\text { (g plant }^{-1} \text { ) }\end{array}$ \\
\hline
\end{tabular}

\begin{tabular}{|c|c|c|c|c|c|c|}
\hline \multicolumn{7}{|l|}{ Amendment } \\
\hline Dry molasses & $27.8 \pm 0.9 b$ & $57.1 \pm 5.2 \mathrm{a}$ & $6.4 \pm 0.5 a$ & $36.9 \pm 1.1 \mathrm{a}$ & $50.6 \pm 2.1 \mathrm{a}$ & $0.9 \pm 0.1 \mathrm{a}$ \\
\hline Wheat bran & $35.7 \pm 1.2 \mathrm{a}$ & $36.9 \pm 4.8 b$ & $5.4 \pm 0.6 a$ & $31.6 \pm 1.1 \mathrm{~b}$ & $41.7 \pm 2.6 b$ & $0.8 \pm 0 \mathrm{a}$ \\
\hline Control & $28.7 \pm 1.1 b$ & $19.7 \pm 4.5 c$ & $3.4 \pm 0.4 b$ & $33.7 \pm 1.1 \mathrm{ab}$ & $37.5 \pm 1.3 b$ & $0.8 \pm 0.1 \mathrm{a}$ \\
\hline \multicolumn{7}{|l|}{ C:N ratio } \\
\hline 10 & $30.4 \pm 1.2$ & $70.0 \pm 6 a$ & $7.1 \pm 0.9 a$ & $36.3 \pm 1.6$ & $53.5 \pm 3.7 \mathrm{a}$ & $1.0 \pm 0.1 \mathrm{a}$ \\
\hline 20 & $30.7 \pm 1.4$ & $48.7 \pm 8.7 \mathrm{~b}$ & $6.3 \pm 0.6 a$ & $34.6 \pm 1.6$ & $45.9 \pm 4 a b$ & $0.8 \pm 0.1 \mathrm{~b}$ \\
\hline \multirow[t]{2}{*}{ Control } & $28.7 \pm 1.1$ & $19.7 \pm 4.5 d$ & $3.4 \pm 0.4 b$ & $33.7 \pm 1.1$ & $37.5 \pm 1.3 b$ & $0.8 \pm 0.1 b$ \\
\hline & \multicolumn{6}{|c|}{$P$-value } \\
\hline Amendment & $<0.001$ & $<0.001$ & 0.004 & 0.002 & 0.001 & NS \\
\hline C:N ratio & NS & $<0.001$ & $<0.001$ & NS & 0.004 & 0.028 \\
\hline Amendment $\times$ C:N ratio & NS & NS & NS & NS & NS & NS \\
\hline
\end{tabular}

Values represent means and standard errors of 8 total replicates (4 replicates $\times 2$ experiments).

(Figure 6D). The only significant difference was observed in culled fruit mass where the highest culled fruit mass was recorded for the sucrose + feather meal ASD treatment for both pepper and eggplant (Figures 6C,D).

There was significant moderate positive relationship between tomato fruit weight with post-ASD total soil inorganic $\mathrm{N}$ (0.4, $P<0.05)$, tomato root biomass with cropping phase soil inorganic $\mathrm{N}(0.4$ to $0.6, P<0.01)$ and a moderate negative correlation between plant $\mathrm{N}$ and dry shoot biomass $(-0.5, P$ $<0.01$ ) in trial 1 (Table 4). For trial 2, total fancy-grade bell pepper yield had a positive moderate relationship with cropping phase soil $\mathrm{NO}_{2}-\mathrm{N}+\mathrm{NO}_{3}-\mathrm{N}$ and total soil inorganic $\mathrm{N}(0.5, P$ $<0.01$ ), but neither correlated significantly to total yield or total marketable yield. Bell pepper leaf $\mathrm{N}$ in trial 2 had a 


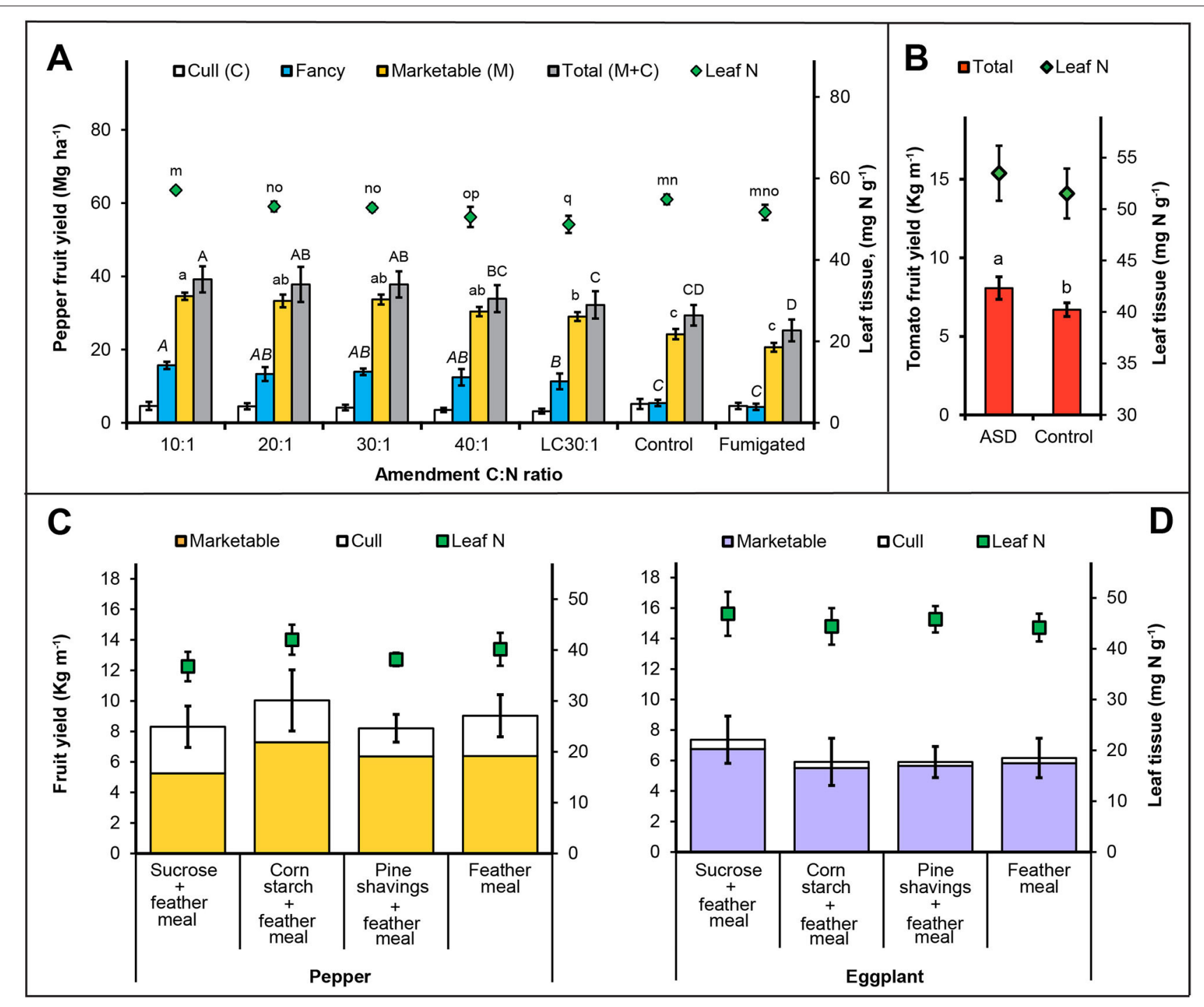

FIGURE 6 | Crop yield and leaf tissue N in response to ASD amendment (A) C:N ratio field study, trial 2, (B) on-farm study, trial 3 and (C) ASD substrate study, trial 4 Bars indicated by similar letters are not significantly different at $\mathrm{P}<0.05$ according to Fisher's protected LSD test. Error bars indicate standard error with eight (A), 12 (B), six (C) and six (D) replicates.

moderate positive relationship with fancy and total marketable yield $(0.6, P<0.001)$. Similarly, total yield in trial 3 was strongly positively correlated with post-ASD soil $\mathrm{NH}_{4}-\mathrm{N}$ and cropping phase soil inorganic $\mathrm{N}(0.7, P<0.001)$. Leaf tissue $\mathrm{N}$ content was moderately correlated to total yield. We did not observe any significant positive correlation of fancy-grade or total marketable yield, leaf $\mathrm{N}$ or post-ASD soil inorganic $\mathrm{N}$ for eggplant or pepper in trial 4 (Table 4).

\section{Discussion}

Soil treatment by ASD has been proven to be an effective method to control various pests, especially fungal pathogens and plant parasitic nematodes (e.g., Shrestha et al. 2016). The effect of ASD treatments on horticultural crop yield is not as comprehensively described in the literature, as much research and developmental work in ASD systems has focused on evaluating mechanisms of plant pathogen control, or on applied research optimizing ASD treatment systems to specific local environmental factors and available amendments to control important diseases of regional cropping systems. The relationship of ASD treatment to crop yield is also complex (Butler et al., 2014a), not unlike the mechanisms that increase crop yield post soil fumigation or solarization (Stapleton et al., 1985; Chen et al., 1991; Stapleton, 2000) or with crop rotation (Bennett et al., 2012) or the addition of organic amendments in aerobic soil environments (Gamliel et al., 2000; Wortman et al., 2017; Chen et al., 2018; Barzee et al., 2019; Bonanomi et al., 2020). First, and perhaps most importantly considering the motivation of ASD treatment or other soil disinfestation practices, is the potential yield benefit of controlling plant diseases as compared to systems without soil disinfestation or soil fumigation treatment. In research studies, this would require sufficient plant disease that negatively impacts 
yield, which is not always predictable given the environmental conditions important to disease occurrence and the difficulty in controlling such conditions in field research. At the same time, ASD systems may also increase crop yield through organicamendment induced changes in soil chemical, physical and biological properties (Butler et al., 2014a; Rosskopf et al., 2015). These changes include beneficial changes to the soil environment post ASD treatment such as increased soil nutrient availability (Butler et al., 2014a; McCarty et al., 2014), increased water or nutrient holding capacity especially in sandy soils (Chen et al., 2018; Minasny and McBratney, 2018), or increased populations and crop-associations of plant growth promoting fungi or bacteria (e.g., Mazzola et al., 2018; Poret-Peterson et al., 2019; Shrestha et al., 2020b).

In a meta-analysis of work published prior to 2016, Shrestha et al. (2016) reported that of 68 published comparisons of an ASD treatment to a non-amended control treatment, ASD treatments had $30 \%$ higher yield than control treatments on average but this was not statistically different. In 55 published comparisons of an ASD treatment to a fumigated treatment, yields were essentially equivalent in ASD and fumigated treatments (ASD yields numerically $6 \%$ higher). Results from this meta-analysis also suggest that yield response can vary due to effects of amendment properties and rates of application, although the limited number of published studies limits inferences that can be made (Shrestha et al., 2016). This is congruent with our understanding of the mechanisms of ASD effects on crop yield, as we would expect both effects on soilborne plant pathogens and soil physical, chemical and biological properties to be affected by amendment properties and application rates (Butler et al., 2014b; Shrestha et al., 2016, 2018a; Mazzola et al., 2018).

In the present study, we show that ASD amendment types and properties such as C:N ratio have important effects on solanaceous crop biomass and yield, even under recommended crop fertilization regimes, and in the relative absence of yield limiting crop disease. To our knowledge, this is the first study to specifically evaluate ASD amendment C:N ratio effects on soil inorganic $\mathrm{N}$, crop $\mathrm{N}$ status and crop yield. At the same time, our results are consistent with other reports of high soil inorganic $\mathrm{N}$ following soil disinfestation with ASD amendments with relatively low C:N ratios (Butler et al., 2014a; McCarty et al., 2014; Di Gioia et al., 2017; Shrestha et al., 2018b). Soil microbial stoichiometry is fairly constrained within a C:N ratio of $\sim 5: 1$ to $7: 1$, which along with microbial energetic needs causes substrate C:N ratios above $\sim 20: 1$ to lead to $\mathrm{N}$ limitations on microbial decomposition and reduced available soil inorganic N (Sinsabaugh et al., 2013; Spohn, 2015). In the absence of data to optimize ASD treatments to both control important soilborne plant pathogens and to promote crop yield, crop managers may find utility in using ASD amendment mixtures with a C:N ratio near 20:1 (and amendment rates

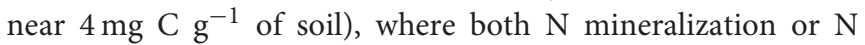
immobilization caused by the added amendment will be limited. This will allow for minimal changes to existing solanaceous crop fertilization practices, while still potentially improving crop yield compared to grower standard treatments, as we observed in trials 2 and 3. As our trials were conducted across relatively similar soil and environmental conditions typical to many warm-temperate to tropical production conditions for solanaceous crops, our results may be less applicable to environmental conditions typical to production of cooler climate crops or with vastly different soil types (such as coarsely textured soils).

While we expect that ASD amendment substrate decomposability has important effects on soilborne plant pathogens (e.g., Shrestha et al., 2016, 2021), initial effects on soil inorganic $\mathrm{N}$ in our study did not lead to substantial differences in crop performance, likely because C:N ratios were relatively standardized $(\sim 30: 1)$ across substrates with feather meal, a relatively easily available form of organic $\mathrm{N}$. This suggests that crop performance benefits of ASD treatments (other than soilborne disease suppression) may result from a range of substrate types, if $\mathrm{ASD}$ amendment $\mathrm{C}: \mathrm{N}$ ratios are relatively low. Highly recalcitrant substrates, such as the pine shavings in trial 4, likely do not induce microbial growth at rates sufficient to significantly induce $\mathrm{N}$ immobilization during the ASD incubation or during the post-ASD cropping phase. This suggests that there are limits to use of C:N ratio in guiding crop fertility decisions with ASD treatment (e.g., Bengtsson et al., 2003). While highly recalcitrant substrates are not typically suitable for ASD treatment due to low decomposability and thus low production of anaerobic decomposition metabolites during treatment incubation, amendment mixtures can contain relatively recalcitrant forms of $\mathrm{C}$ (such as lignified components of cover crop biomass or crop residues, or highly processed $\mathrm{C}$ compounds in composted materials), and these components may exert less influence on post-treatment $\mathrm{N}$ availability than would be evident from C:N ratio alone. At the same time, amendment mixtures often do not mineralize in a purely additive manner, as antagonistic and synergistic (i.e., priming) effects of amendment mixture components can alter decomposition rates of mixed residues (e.g., Bending and Turner, 1999; Maisto et al., 2011; Truong and Marschner, 2018). Given there are many well-developed simulation models to describe and estimate nitrogen transformation dynamics in anaerobic conditions (e.g., DNDC; Li, 1996) and decomposition dynamics and $\mathrm{N}$ mineralization from organic residues (e.g., CERES-N; Quemada and Cabrera, 1995) based on environmental conditions and biochemical composition, future work to model these dynamics using similar tools for ASD treatment systems would likely have high utility for crop managers.

\section{DATA AVAILABILITY STATEMENT}

The raw data supporting the conclusions of this article will be made available by the authors, without undue reservation.

\section{AUTHOR CONTRIBUTIONS}

US co-designed all trials and conducted trials 1, 2 and 4, assisted in trial 3, performed related lab work, completed 
all statistical analyses, and wrote the initial draft of the manuscript. KS conducted trial 3, assisted in trial 4. DB codesigned all trials, obtained funding for all trials, supervised trial completion in his lab group, and provided critical revisions to the manuscript draft.

\section{FUNDING}

Funding provided by the National Institute of Food and Agriculture, U.S. Department of Agriculture (USDA), under award number 2012-51102-20293 (Methyl Bromide Transitions Program) and Hatch project 1014161, and by the USDA Agricultural Research Service under award A15-0229.

\section{REFERENCES}

Barzee, T. J., Edalati, A., El-Mashad, H., Wang, D., Scow, K., and Zhang, R. (2019). Digestate biofertilizers support similar or higher tomato yields and quality than mineral fertilizer in a subsurface drip fertigation system. Front. Sustain. Food Syst. 3:58. doi: 10.3389/fsufs.2019.00058

Bending, G. D., and Turner, M. K. (1999). Interaction of biochemical quality and particle size of crop residues and its effect on the microbial biomass and nitrogen dynamics following incorporation into soil. Biol. Fertil. Soils 29, 319-327. doi: 10.1007/s003740050559

Bengtsson, G., Bengtson, P., and Månsson, K. F. (2003). Gross nitrogen mineralization-, immobilization-, and nitrification rates as a function of soil $\mathrm{C} / \mathrm{N}$ ratio and microbial activity. Soil Biol. Biochem. 35, 143-154. doi: 10.1016/S0038-0717(02)00248-1

Bennett, A. J., Bending, G. D., Chandler, D., Hilton, S., and Mills, P. (2012). Meeting the demand for crop production: the challenge of yield decline in crops grown in short rotations. Biol. Rev. 87, 52-71. doi: 10.1111/j.1469-185X.2011.00184.x

Bonanomi, G., De Filippis, F., Zotti, M., Idbella, M., Cesarano, G., Al-Rowaily, S., et al. (2020). Repeated applications of organic amendments promote beneficial microbiota, improve soil fertility and increase crop yield. Appl. Soil Ecol. 156:103714. doi: 10.1016/j.apsoil.2020.103714

Butler, D. M., Kokalis-Burelle, N., Albano, J. P., McCollum, T. G., Muramoto, J., Shennan, C., et al. (2014a). Anaerobic soil disinfestation (ASD) combined with soil solarization as a methyl bromide alternative: vegetable crop performance and soil nutrient dynamics. Plant Soil 378, 365-381. doi: 10.1007/s11104-014-2030-Z

Butler, D. M., Ownley, B. H., Dee, M. E., Inwood, S. E. E., McCarty, D. G., Shrestha, U., et al. (2014b). Low carbon amendment rates during anaerobic soil disinfestation (ASD) at moderate soil temperatures do not decrease viability of Sclerotinia sclerotiorum sclerotia or Fusarium root rot of common bean. Acta Hortic. 1044, 203-208. doi: 10.17660/ActaHortic.2014.10 44.23

Castenson, K. L., and Rabenhorst, M. C. (2006). Indicator of reduction in soil (IRIS): Evaluation of a new approach for assessing reduced conditions in soil. Soil Sci. Soc. Am. J. 70, 1222-1226. doi: 10.2136/sssaj2005. 0130

Chen, Y., Camps-Arbestain, M., Shen, Q., Singh, B., and Cayuela, M. L. (2018). The long-term role of organic amendments in building soil nutrient fertility: a meta-analysis and review. Nutri. Cycl. Agroecosyst. 111, 103-125. doi: 10.1007/s10705-017-9903-5

Chen, Y., Gamliel, A., Stapleton, J. J., and Aviad, T. (1991). "Chemical, physical, and microbial changes related to plant growth indisinfested soils," in Soil Solarization, eds J. Katan and J.E. DeVay (CRC Press, Boca Raton), 103-129.

Di Gioia, F., Ozores-Hampton, M., Zhao, X., Thomas, J., Wilson, P., Li, Z., et al. (2017). Anaerobic soil disinfestation impact on soil nutrients dynamics and nitrous oxide emissions in fresh-market tomato. Agric. Ecosyst. Environ. 240, 194-205. doi: 10.1016/j.agee.2017.02.025

\section{ACKNOWLEDGMENTS}

We thank lab members of Dr. Butler's lab, staff at the University of Tennessee East Tennessee Research \& Education Center, Organic Crops Unit, Knoxville, TN and the UT Plateau Research Education Center, Crossville, TN, and John Ledbetter, Hines Valley Organic Farm, Lenoir City, TN for their assistance with research studies.

\section{SUPPLEMENTARY MATERIAL}

The Supplementary Material for this article can be found online at: https://www.frontiersin.org/articles/10.3389/fsufs. 2021.694820/full\#supplementary-material

Gamliel, A., Austerweil, M., and Kritzman, G. (2000). Non-chemical approach to soilborne pest management-organic amendments. Crop Prot. 19, 847-853. doi: 10.1016/S0261-2194(00)00112-5

Gilardi, G., Pugliese, M., Gullino, M. L., and Garibaldi, A. (2020). Evaluation of different carbon sources for anaerobic soil disinfestation against Rhizoctonia solani on lettuce in controlled production systems. Phytopathol. Mediterr. 59, 77-96. doi: 10.14601/Phyto-10911

Guo, H., Di Gioia, F., Zhao, X., Ozores-Hampton, M., Swisher, M. E., Hong, J., et al. (2017). Optimizing anaerobic soil disinfestation for fresh market tomato production: nematode and weed control, yield, and fruit quality. Sci. Hortic. 218, 105-116. doi: 10.1016/j.scienta.2017.01.054

Inglett, P. W., Reddy K. R. and Corstanje R. (2005) "Anaerobic soils", in Encyclopedia of Soils in the Environment. Hillel, D (ed). Elsevier: Amsterdam.

Kemble, J., Quesada-Ocampo, L., Ivors, K., Jennings, K., and Walgenbach, J. F. (2013). Southeastern Vegetable Crop Handbook. Lincolnshire, IL, Vance Publishing.

Kissel, D. E., Sonon, L., Vendrell, P. F., and Isaac, R. A. (2009). Salt concentration and measurement of soil pH. Commun. Soil Sci. Plant Anal. 40, 179-187. doi: 10.1080/00103620802625377

Knewtson, S. J. B., Kirkham, M. B., Janke, R. R., Murray, L. W., and Carey, E. E. (2012). Soil quality after eight years under high tunnels. HortSci. Horts 47:1630. doi: 10.21273/HORTSCI.47.11.1630

Li, C. (1996). "The DNDC model," in Evaluation of soil organic matter models (Berlin: Springer) 263-267.

Maisto, G., De Marco, A., Meola, A., Sessa, L., and Virzo De Santo, A. (2011). Nutrient dynamics in litter mixtures of four Mediterranean maquis species decomposing in situ. Soil Biol. Biochem. 43, 520-530. doi: 10.1016/j.soilbio.2010.11.017

Mazzola, M., Muramoto, J., and Shennan, C. (2018). Anaerobic disinfestation induced changes to the soil microbiome, disease incidence and strawberry fruit yields in California field trials. Appl. Soil Ecol. 127, 74-86. doi: 10.1016/j.apsoil.2018.03.009

McCarty, D. G., Inwood, S. E. E., Ownley, B. H., Sams, C. E., Wszelaki, A. L., and Butler, D. M. (2014). Field evaluation of carbon sources for anaerobic soil disinfestation in tomato and bell pepper production in Tennessee. HortScience 49, 272-280. doi: 10.21273/HORTSCI.49.3.272

Minasny, B., and McBratney, A. (2018). Limited effect of organic matter on soil available water capacity. Eur. J. Soil Sci. 69, 39-47. doi: 10.1111/ejss.12475

Paudel, B. R., Di Gioia, F., Zhao, X., Ozores-Hampton, M., Hong, J. C., KokalisBurelle, N., et al. (2018). Evaluating anaerobic soil disinfestation and other biological soil management strategies for open-field tomato production in Florida. Renew. Agric. Food Syst. 1-12. doi: 10.1017/S1742170518000571

Poret-Peterson, A. T., Albu, S., McClean, A. E., and Kluepfel, D. A. (2019). Shifts in soil bacterial communities as a function of carbon source used during anaerobic soil disinfestation. Front. Environ. Sci. 6:160. doi: 10.3389/fenvs.2018.00160

Quemada, M., and Cabrera, M. L. (1995), CERES-N Model Predictions of nitrogen mineralized from cover crop residues. Soil Sci. Soc. Am. J. 59, 1059-1065. doi: $10.2136 /$ sssaj1995.03615995005900040015x 
Rabenhorst, M. (2012). Simple and reliable approach for quantifying IRIS tube data. Soil Sci. Soc. Am. J. 76, 307-308. doi: 10.2136/sssaj2011. $0267 \mathrm{n}$

Rosskopf, E. N., Chellemi, D. O., Kokalis-Burelle, N., and Church, G. T., (2005). Alternatives to methyl bromide: A Florida perspective. APSnet Feature [Online]. Available online at: http://www.apsnet.org/publications/ apsnetfeatures/Documents/2005/MethylBromideAlternatives.pdf.

Rosskopf, E. N., Serrano-Pérez, P., Hong, J., Shrestha, U., Rodríguez-Molina, M., d,.C., et al. (2015). "Anaerobic soil disinfestation and soilborne pest management," in Organic Amendments and Soil Suppressiveness in Plant Disease Management, eds. K.M. Meghvansi and A. Varma. (Cham, Switzerland: Springer International Publishing) 277-305.

Shennan, C., Muramoto, J., Lamers, J., Mazzola, M., Rosskopf, E. N., KokalisBurelle, N., et al. (2014). Anaerobic soil disinfestation for soil borne disease control in strawberry and vegetable systems: current knowledge and future directions. Acta Hortic. 1044, 165-175. doi: 10.17660/ActaHortic.2014. 1044.20

Shrestha, U., Aug,é, R., and Butler, D. M. (2016). A meta-analysis of impact of anaerobic soil disinfestation on pest suppression and yield of horticultural crops. Front. Plant Sci. 7(1254). doi: 10.3389/fpls.2016.01254

Shrestha, U., Collins, R. L., Swilling, K. J., Ownley, B. H., and Butler, D. M. (2020a). Role of substrate decomposability and volatile fatty acids in anaerobic soil disinfestation activity against Sclerotinia sclerotiorum. Acta Hortic., 71-82. doi: 10.17660/ActaHortic.2020.1270.8

Shrestha, U., Dee, M. E., Ownley, B. H., and Butler, D. M. (2018a). Anaerobic soil disinfestation reduces germination and affects colonization of Sclerotium rolfsii sclerotia. Phytopathology 108, 342-351. doi: 10.1094/PHYTO-04-170152-R

Shrestha, U., Dee, M. E., Piya, S., Ownley, B. H., and Butler, D. M. (2020b). Soil inoculation with Trichoderma asperellum, T. harzianum or Streptomyces griseoviridis prior to anaerobic soil disinfestation (ASD) does not increase ASD efficacy against Sclerotium rolfsii germination. Appl. Soil Ecol. 147:103383. doi: 10.1016/j.apsoil.2019.103383

Shrestha, U., Ownley, B. H., Bruce, A., Rosskopf, E. N., and Butler, D. M. (2021). Anaerobic soil disinfestation efficacy against Fusarium oxysporum is affected by soil temperature, and amendment type, rate and C: N ratio. Phytopathology 276. doi: 10.1094/PHYTO-07-20-0276-R

Shrestha, U., Rosskopf, E., and Butler, D. M. (2018b). Effect of anaerobic soil disinfestation amendment type and C: $\mathrm{N}$ ratio on Cyperus esculentus tuber sprouting, growth and reproduction. Weed Res. 58, 379-388. doi: $10.1111 /$ wre. 12318

Sims, G. K., Ellsworth, T. R., and Mulvaney, R. L. (1995). Microscale determination of inorganic nitrogen in water and soil extracts. Commun. Soil Sci. Plant Anal. 26, 303-316. doi: 10.1080/00103629509369298
Sinsabaugh, R. L., Manzoni, S., Moorhead, D. L., and Richter, A. (2013). Carbon use efficiency of microbial communities: stoichiometry, methodology and modelling. Ecol. Lett. 16, 930-939. doi: 10.1111/ele.12113

Spohn, M. (2015). Microbial respiration per unit microbial biomass depends on litter layer carbon-to-Nitrogen ratio. Biogeosciences 12, 817-823. doi: 10.5194/bg-12-817-2015

Stapleton, J. J. (2000). Soil solarization in various agricultural production systems. Crop Prot. 19, 837-841. doi: 10.1016/S0261-2194(00)00111-3

Stapleton, J. J., Quick, J., and Devay, J. E. (1985). Soil solarization: Effects on soil properties, crop fertilization and plant growth. Soil Biol. Biochem. 17, 369-373. doi: 10.1016/0038-0717(85)90075-6

Strauss, S., and Kluepfel, D. (2015). Anaerobic soil disinfestation: a chemicalindependent approach to pre-plant control of plant pathogens. J. Integr. Agric. 14, 2309-2318. doi: 10.1016/S2095-3119(15)61118-2

Truong, T. H. H., and Marschner, P. (2018). Respiration, available N and microbial biomass $\mathrm{N}$ in soil amended with mixes of organic materials differing in $\mathrm{C} / \mathrm{N}$ ratio and decomposition stage. Geoderma 319, 167-174. doi: 10.1016/j.geoderma.0.2018.01.012

USDA-AMS. (2005). United states standards for grades of sweet peppers. [Online]. U.S. Department of Agriculture (USDA), Agriculture Marketing Service. Available online at: https://www.ams.usda.gov/grades-standards/ sweet-peppers-grades-and-standards [Accessed April 2013].

Wortman, S. E., Holmes, A. A., Miernicki, E., Knoche, K., and Pittelkow, C. M. (2017). First-season crop yield response to organic soil amendments: a meta-analysis. Agron. J. 109, 1210-1217. doi: 10.2134/agronj2016.10.0627

Conflict of Interest: The authors declare that the research was conducted in the absence of any commercial or financial relationships that could be construed as a potential conflict of interest.

Publisher's Note: All claims expressed in this article are solely those of the authors and do not necessarily represent those of their affiliated organizations, or those of the publisher, the editors and the reviewers. Any product that may be evaluated in this article, or claim that may be made by its manufacturer, is not guaranteed or endorsed by the publisher.

Copyright (c) 2021 Shrestha, Swilling and Butler. This is an open-access article distributed under the terms of the Creative Commons Attribution License (CC BY). The use, distribution or reproduction in other forums is permitted, provided the original author(s) and the copyright owner(s) are credited and that the original publication in this journal is cited, in accordance with accepted academic practice. No use, distribution or reproduction is permitted which does not comply with these terms. 